\title{
SOME REFLECTIONS ON CONTRACT LAW THEORY*
}

\author{
Brian BIX
}

Resumen:

La divergencia que existe entre la forma en que hablamos del derecho contractual y la actual experiencia contractual, la obligación moral de las partes contratantes de mantener un contrato, y el papel del gobierno en la regulación de los contratos, son los tres asuntos principales que se abordan en este artículo. El análisis señala la perspectiva de una más estrecha y cautelosa visión del derecho contractual, pues la teoría propuesta no es una más de las teorias generales, sino una teoría desafiante enfocada en las reglas de un tiempo y lugar específico.

\begin{abstract}
:
The existing divergence between how we talk about contract law and actual contract experience, the parties moral obligation to keep contracts and the government's role in regulating contracts, are the three main issues addressed in this article. The analysis of this article points to a narrower and more cautious approach to contract law, not towards a general theory, but one focused on the rules of a single time and place.
\end{abstract}

* This article derives from work which will become part of a forthcoming book on Contract Law for the Series, Cambridge Introductions to Philosophy of Law. I am grateful for the comments and suggestions of Matthew D. Adler, Peter A. Alces, Larry Alexander, Curtis Bridgeman, Sean Coyle, William A. Edmundson, Daniel A. Farber, Bruce W. Frier, Daniel J. Gifford, Robert W. Gordon, Oren Gross, Robert A. Hillman, Peter Huang, Matthew H. Kramer, Jody S. Kraus, Jeff Lipshaw, Brett H. McDonnell, David McGowan, Alexander M. Meiklejohn, Dennis Patterson, Mark D. Rosen, Keith A. Rowley, Hanoch Sheinman, Stephen A. Smith, Jane K. Winn, and participants at faculty workshops at the University of Illinois Law School, the University of Minnesota Law School, and the William S. Boyd School of Law, and the Analytical Legal Philosophy Conference. 
SUMmARY: I. Introduction. II. Gap between Ideal and Reality. III. Theories of Contract Law. IV. Theory Meets Practice. V. Rethinking Contract Law. VI. The Moral Obligation to Keep Contracts. VII. Implications for Government Regulation. VIII. Note on Rights and Remedies. IX. General Theory. X. General Contract Law. XI. "Contract" and "Law". XII. Consequences. XIII. Note on Proving a Negative. XIV. Conclusion. XV. Bibliography.

\section{INTRODUCTION}

What does it mean to have a contract law theory? A theory is an explanation of the subject of the theory, ${ }^{1}$ but what does it mean to explain contract law? If someone asks you to explain the game of baseball or a legislative process, one's initial response would be to detail the rules under which the activity occurs. However, those seeking an explanation of contract law are looking for something more than a recitation of doctrinal rules. The questioner would likely want a deeper explanation, one that discussed how the rules and practices got to be the way they are (and this is the role history plays in theories of doctrinal areas) and why they have been maintained rather than radically revised (and here is the place for justification of some sort).

However, the process of explanation is complicated by the dynamic nature of law (in particular - though not exclusively - common law areas of law), where not only is it the case that the law changes regularly and significantly, but also that explanations, justifications, and recharacterizations play a role in those changes. ${ }^{2}$ This is the sort of feedback that

1 Barnett ("A Consent Theory of Contract", Columbia Law Review, vol. 86, 1986 , p. 269) asserts (in the context of presenting and defending his own theory of Contract Law) that "[t]heories are problem-solving devices" and that "[w]e assess the merits of a particular theory by its ability to solve the problems that give rise for a need for a theory". As this Article will argue, I think this view of theory in general, and Contract theory in particular, is too focused on the perspective of the judge or advocate, and not sufficiently on the observer who may not have an immediate stake in doctrinal disputes.

2 In discussing alternative objectives for theories, Moore (Moore, Michael S., "Theories of Areas of Law", San Diego Law Review, vol. 37, 2000, p. 732; "A Theory 
Dworkin ${ }^{3}$ captured in his idea of "constructive interpretation". And as Michael Moore ${ }^{4}$ has pointed out, theory -at least, theorizing of a sort - plays a role within legal reasoning and legal practice, as much as being about legal reasoning and legal practice.

Before turning to these questions of theory and meta-theory, this Article will deal, first, with the divergence between the way we ${ }^{5}$ talk about contract law and actual contract experience. Secondly, the Article will consider some implications of this divergence, and of current contracting practices, for how we should think about our obligation to keep contracts and how the government should regulate contracts.

To some extent, the exploration will be one regarding what role theory can and does play, and whether our current theories of contract law might be doing more to legitimate unjust practices than to explain the doctrinal area. The Article will consider, on the normative side, what current contracting practices might entail in the way of the contracting parties' moral obligations to keep contracts and the government's role in regulating contracts.

\section{GaP BETWEen IDEAL AND REALity}

The ideal of "freedom of contract" (and its corollary, "freedom from contract" 6 ) is that one takes on contractual

of Criminal Law Theories", Tel Aviv University Studies in Law, vol. 10, 1990, pp. 120 and 121) distinguishes explanation (in terms of historical-causal discussions) from description (a discovery of patterns that may be distant from either historical discussion or justification/rational reconstruction). The distinction is useful, but I prefer to use "explanation" broadly, because I think that the idea of "explanation" ranges over a number of different objectives, and that it is important to emphasize that scope.

3 Dworkin, Ronald, Law's Empire, Cambridge, Mass., Harvard University Press, 1986, pp. 49-53.

4 Moore, Michael S., "A Theory of Criminal Law Theories", Tel Aviv University Studies in Law, cit., nota 2, pp. 118-129.

5 "We" used both narrowly to mean legal academics, and more broadly to include the general population.

6 See Symposium, "Freedom from Contract", Wisconsin Law Review, vol. 2004, pp. 261-836. 
liability to the extent, and only to the extent, that one has freely chosen to do so. This is an ideal that is not always fully realized, for a variety of reasons, many of them relatively "innocent" and uncontroversial - e.g., the move from subjective to objective tests for formation ${ }^{7}$ and interpretation 8 ; and some non-contractual grounds for liability (e.g., promissory estoppel, promissory restitution, and unjust enrichment). These modifications have been imposed to serve interests of economic efficiency ${ }^{9}$ and/or fairness. ${ }^{10}$

At the present time, though, the deviations from the ideal of freedom of contract are not merely minor ones created on the margins to make contract law easier to administer or to protect the most vulnerable. Rather, the deviations from the ideal are pervasive, especially in consumer transactions. It is a commonplace that a relatively small percentage of the contracts most of us enter match the model of face-to-face negotiation of terms that underlies most theories about contract law (both classical and contemporary). It is, therefore, misleading to argue that face-to-face-negotiated agreements are the "paradigm case" of contracts, and that the adhesion contracts ${ }^{11}$ that dominate commercial life are

7 E.g., Farnsworth, E. Allan, Contracts, 4th. ed., New York, Aspen Publishers, pp. 114-117.

8 Ibidem, pp. 445-452.

9 With the objective standard making enforceability of contracts much more predictable.

10 With the equitable claims of promissory estoppel, promissory restitution, and unjust enrichment; though there is also an element of fairness in enforcing agreements where one of the parties reasonably understood the other party to be bound, based on the other party's public actions, whatever the other party's private understandings.

11 "Adhesion contracts" are standard forms presented to less sophisticated parties with less bargaining power and few alternatives on a "take it or leave it basis" (e.g., Slawson, W. David, "Standard Form Contracts and Democratic Control of Lawmaking Power”, Harvard Law Review, vol. 84, 1971, pp. 529-566; Rakoff, Todd D., "Contracts of Adhesion: An Essay in Reconstruction", Harvard Law Review, vol. 96, 1983, pp. 1173-1284). One might reasonably distinguish form contracts presented to consumers in a retail context from the use of standard forms in dealings between merchants (e.g., American Law Institute, "Principles of the Law of Software Contracts", Council Draft, num. 1, November 7, 2006, pp. 108-119). 
merely marginal or inferior instantiations. ${ }^{12}$ The conventional view - portraying face-to-face-negotiated agreements as the normal or usual contract - has distorted of our understanding of contemporary contract law, and perhaps also legitimized unjust practices. ${ }^{13}$

There are a variety of practices that particularly raise questions regarding contracts - questions that are sometimes posed in terms of consent ("full," "fully voluntary," or "informed" consent), and sometimes in terms of fairness or public policy. Along with the now-familiar examples of standard form agreements - and especially "adhesion contracts"modern contract practice has also given us click-through ("clickwrap") agreements, ${ }^{14}$ agreements based solely on terms posted on an Internet site where use or continued access would be deemed as assent ("browsewrap"), ${ }^{15}$ software licenses, ${ }^{16}$ and greater use of mandatory arbitration ${ }^{17}$ and

12 There is a rich tradition in theories of social practices of constructing a theory around the most sophisticated, richest, or most developed instance of a category, even if the vast majority of that category's members are then to be characterized as "lesser" or "marginal" (e.g., Finnis, John, Natural Law and Natural Rights, Oxford, Clarendon Press, 1980, pp. 9-11). This is an approach with which I have some sympathy (particularly in the context of theories about the nature of law generally); however, the approach's theoretical benefits must always be weighed against the potential distorting or legitimating effects.

13 My point about legitimation in this paper is not to be confused with Grant Gilmore's argument that there is an incoherence between overarching (Willistonian) theory and mundane contract doctrine (Gilmore, Grant, The Death of Contract, Columbus, Ohio, Ohio State University Press, 1974, pp. 42-53).

14 E.g., i.Lan Systems, Inc. v. Netscout Service Level Corp., 183 F. Supp. 2d 328 (D. Mass. 2002) (clickthrough license terms enforceable); Mortgage Plus, Inc. v. DocMagic, Inc., No. 03-2582-GTV-DJW, 2004 WL 2331918 (D. Kan. 2004) (clickwrap agreement enforceable, including forum selection clause).

15 See, e.g., Register.Com v. Verio, 356 F.3d 393 (2nd. Cir. 2004) (user bound to terms when it repeatedly accessed site where terms were posted).

16 E.g., Specht v. Netscape Communications Corp., 306 F.3d 17 (2nd. Cir. 2002) (arbitration terms in software license did not become part of agreement because terms were not brought sufficiently to the attention of the licensees); $c f$. ProCD, Inc. v. Zeidenberg, 86 F.3d 1447 (7th. Cir. 1996) (terms inside box of software bind consumers who use the software after an opportunity to read the terms and return the product).

17 Under the Federal Arbitration Act (9 U.S.C. §§ 1-16), as construed by Supreme Court decisions, there is a strong general federal policy for enforcing arbitration provisions. See Buckeye Check Cashing v. Cardegna, 126 S. Ct. 1204 
forms in the box sent after the purchase. ${ }^{18}$ These are cases where our doubts regarding enforcement of the agreement usually come from a belief that one party's assent was less than fully voluntary, either because of inadequate information or inadequate alternatives. ${ }^{19}$ Most obviously, terms are often not read (or expected to be read), and frequently are not fully understood even when read. However, the questions about modern contracts extend deeper and broader than a concern about notice.

Characterizing the objection as one of "inadequate information or inadequate alternatives" is common to economic analyses (e.g., Craswell ${ }^{20}$ ) Some might prefer a more direct reference, at least in some circumstances, to the substantive unfairness of certain terms. The response of those who prefer to speak about information and alternatives, I assume, is that if a party, adult and mentally competent, with full information and adequate alternatives, would choose to accept a particular term, it would be unduly paternalistic for others to object. Nonetheless, there may well still be occasions when reference to "(substantive) unfairness" seems to get to the heart of our objection more than "inadequate information" / "inadequate alternatives". For example, the problem of a mandatory arbitration case where the firm hired to do First USA's credit card arbitration decided for

(2006). However, recent federal legislation has also recognized the exploitative potential of mandatory arbitration, when the John Warner National Defense Authorization Act included a section (section 670) that made mandatory arbitration provisions in consumer credit agreements with a member of the U.S. military unlawful and unenforceable. 10 U.S.C. §§ $987(\mathrm{e})(3),(\mathrm{f})(4)$.

18 E.g., Klocek v. Gateway, Inc., 104 F. Supp.2d 1332 (D. Kan. 2000) (terms sent in box after oral agreement to purchase do not become part of agreement under UCC § 2-207); cf. Hill v. Gateway 2000, 105 F.3d 1147 (7th. Cir. 1997) (holding that terms did become part of the agreement through the purchaser's failure to object after receiving the box with the terms).

19 Again, I want to emphasize that I am focusing primarily on consumer commercial transactions. As will be discussed, the concerns may be less (and, at times, different) for other sorts of transactions.

20 Craswell, Richard, "Property Rules and Liability Rules in Unconscionability and Related Doctrines", University of Chicago Law Review, vol. 60, 1993. 
First USA $99.6 \%$ of the time ${ }^{21}$ does not seem to be fully captured by the claim, even if true, that most consumers would choose a different credit card provider if they knew about these figures, and could find a provider that did not use the same arbitration service. ${ }^{22}$

(Of course, contracting practices of this sort do not always lead to unjust outcomes. Some companies may put one-sided terms in their contracts, but then not enforce them, seeing other practices - e.g., allowing returns and exchanges of goods even after use- as more likely to create consumer loyalty. ${ }^{23}$ Anecdotes of good corporate behavior may match in number the anecdotes of sharp practices, but there are certainly enough of the latter to raise concerns).

The general response of contract law to the complaints grounded on failures to achieve fully voluntary assent - just like the general response of most people (lawyers or otherwise) - is that such complaints are not relevant, as parties should be held to the terms for which they have shown outward consent - through their signature, click-through, or verbal agreement (This conventional response usually allows for exceptions in extreme cases, and courts in fact have a number of doctrinal defenses - e.g., fraud, economic duress, reasonable expectations, or unconscionability - they can use to excuse performance in such cases.) The argument goes that contracting parties - at least mentally competent adults who have not been subject to duress or fraud- are able to look after their own interests, and, in fact, are better posi-

21 See Mayer, Caroline E., "Win Some, Lose Rarely? Arbitration Forum's Rulings Called One-Sided", Washington Post, March 1, 2000. The firm, National Arbitration Forum, provided documentation (for litigation) which revealed 87 cases where the card-holder prevailed, as against 19,618 in which First USA prevailed (NCLC 2005, 2, 19).

22 Apparently, National Arbitration Forum, was being used by "many other credit-card firms and retailers, such as American Express and Best Buy". See Mayer, Caroline E., "Win Some, Lose Rarely? Arbitration Forum's Rulings Called One-Sided", Washington Post, cit., note 21.

23 See Bebchuk, Lucian A. and Posner, Richard A., "One-Sided Contracts in Competitive Consumer Markets", Michigan Law Review, vol. 104, 2006, pp. 827-835. 
tioned to know and protect their interests than any legislature or court is. Therefore, contracting parties should be bound to what they sign or to which they otherwise assent. If they do not read all the provisions in the standard form or on the scroll-down terms in the software or on the Internet site, so much the worse for them.

This response is grounded in strong intuitions regarding autonomy and responsibility, and must be taken seriously. At the same time, one may see unexpected exceptions and complications when one tries to translate this general intuition into a more precise theory of moral and legal obligation regarding agreements. Before attempting this, a few words might be helpful, regarding theorizing about doctrinal areas of law.

\section{THEORIES OF CONTRACT LAW}

Theories about doctrinal areas of law - theories of property or contract or tort- are common and well-known 24 (this topic is discussed at greater length in the Appendix). Most such theories sit uneasily between description and prescription/evaluation. On one hand, they purport to fit most of the existing rules and practices; on the other hand, they re-characterize the practices to make them as coherent and/or as morally attractive as possible. ${ }^{25}$ This sort of approach to theorizing comes under various titles: rational reconstruction, "philosophical foundations of the common

24 E.g., Owen David (ed.), Philosophical Foundations of Tort Law, Oxford, Clarendon Press, 1995; Weinrib (The Idea of Private Law, Cambridge, Mass., Harvard University Press, 1995); Fried (Contract as Promise: A Theory of Contractual Obligation, Cambridge, Mass., Harvard University Press, 1981).

25 Moore ("A Theory of Criminal Law Theories", Tel Aviv University Studies in Law, cit., nota 2, 124-129) points out that theories of a line of cases or a whole area of doctrine can never be entirely descriptive, for there are an indefinite number of alternative theories that completely (or, assuming the possibility of dismissing some cases as mistaken, fit adequately) the relevant cases. To choose among those alternative theories, one must have an evaluative standard. 
law", and constructive interpretation. ${ }^{26}$ As both Dworkin ${ }^{27}$ and Michael Moore 28 have argued, there is a strong connection between theories of law understood this way, and the way judges and advocates argue about what the law requires in some novel case.

While this kind of theorizing can be quite valuable - both in terms of explaining an ongoing practice, and because of the role such theorizing has in the development (and teaching) of law- one might want to take the theory a step further; one might ask questions of evaluation or justification of the practice, even as "reconstructed". Assuming a theory of contract law (or some other area of the law) that broadly fits current rules and practices, and even granting some leeway to re-characterize those rules and practices "charitably," one might ask the question, "how should we evaluate the area of law as a matter of morality or policy?". In this section, I will give a brief overview of current theories of contract, followed by an initial look at the moral/evaluative side of the question.

Despite the limitations of the "freedom of contract" ideal in current practice, that ideal informs, for many, the justification for the enforcement of agreements. When commentators try to express that ideal in terms that carry theoretical weight while also matching current doctrinal rules, the result is usually an analysis in terms of promise, reliance, or efficiency. ${ }^{29}$

The promise-based or autonomy argument may be the most straightforward, 30 and the one that best connects with

26 Dworkin, Ronald, Law's Empire, cit., nota 3.

27 Idem.

28 Moore, Michael S., "A Theory of Criminal Law Theories", Tel Aviv University Studies in Law, cit., nota 2, pp. 128 y 129.

29 For one recent, useful overview, see Smith "'Towards a Theory of Contract," Oxford Essays in Jurisprudence, in Horder, Jeremy (ed.), Fourth Series, Oxford, Oxford University Press, 2000, pp. 107-129).

30 What has come to be known as the promise or autonomy approach in the US and the UK, was also developed under the rubric of "will theory," particularly in Continental Europe (e.g., Gordley, James, The Philosophical Origins of Modern Contract Doctrine, Oxford, Clarendon Press, 1991). 
lay attitudes towards contracts: contracts are promises, and one has a moral obligation - and should have a legal obligation - to keep one's promises. At a more abstract or more philosophical level, the discussion is often in terms of "autonomy." The promise or autonomy position is most extensively (and famously) expounded in Charles Fried's Contract as Promise. ${ }^{31}$

There are well-known difficulties with the "contract as promise" explanation or justification: among the most obvious being that our legal system fails to enforce many promises - the whole doctrine of consideration being aimed at distinguishing enforceable bargains from unenforceable "mere" promises32 - and that a focus on promise or autonomy fails to explain (and frequently seems inconsistent with) many details of contract law doctrine - in particular the background rules (e.g., remedial and formation rules) and waivable default rules. ${ }^{33}$ Contracting parties are often

31 Fried, Charles, Contract as Promise: A Theory of Contractual Obligation, cit., note 24 .

32 There are equitable doctrines, like promissory reliance (Restatement (Second) of Contracts § 90) and promissory restitution (id., § 86), which make some non-bargain promises enforceable, but the disjunction between the category of promises and the category of enforceable actions remains significant.

33 E.g., Craswell ("Contract Law, Default Rules, and the Philosophy of Promising", Michigan Law Review, vol. 88, 1989, pp. 489-529); cf. Kraus ("Reconciling Autonomy and Efficiency in Contract Law: The Vertical Integration Strategy", in Sosa, Ernest and Villanueva, Enrique (eds.), Philosophical Issues, 11: Social, Political, and Legal Philosophy, Boston, Blackwell Publishers, 2001, pp. 430-436). Fried did not claim otherwise, and presented his theory as much as an argument for reforming current doctrine as an explanation of or justification for existing law. For an important partial defense of Fried against Craswell's critique, see Kraus ("Philosophy of Contract Law", in Coleman, Jules and Shapiro, Scott (eds.), The Oxford Handbook of Jurisprudence and Philosophy of Law, Oxford, Oxford University Press, pp. 717-732).

Smith ("Towards a Theory of Contract", en Horder, Jeremy (ed.), Oxford Essays in Jurisprudence, cit., nota 29, and by the same author, Introduction to Contract Theory, Oxford, Clarendon Law Series, 2004), following Raz ("Promises in Morality and Law" (book review), Harvard Law Review, vol. 95, 1982, pp. 916-938) and others, also argues that enforcing contracts on the basis of promises potentially violates "the harm principle" - the view, associated with the work of John Stuart Mill, that government is justified in infringing the liberties of its citizens only for the purpose of preventing harm to others. The argument is that forcing people to keep their promises is inconsistent with that principle - at least to the extent that promises 
ignorant of these background rules, and, in any event, cannot usually be characterized as having actively chosen them. ${ }^{34}$

Modern consent theories of contract law (e.g., Barnett) ${ }^{35}$ shift the focus away from an act of promising to "a manifest intention to be legally bound". ${ }^{36}$ Barnett $^{37}$ emphasized that this theory of contract law should be seen within the context of a larger theory of entitlements, and the conditions under which entitlement transfers are valid.

There is something eminently sensible about a theory of contract law centered on consent. For while promise, reliance, or wealth maximization (understanding each of these in a robust, rather than diluted or metaphorical sense) is only unevenly present in the various kinds of transactions we associate with contract, some form of assent is basically universally present - and universally required for a valid and enforceable contract.

are enforced beyond the point necessary to protect other people's reasonable reliance (and limiting the promise theories or contract law in that way move us back towards the reliance theories of contract). Here, it may be useful to use the law and economics view of contract to supplement or correct a promissory account: thus, American contract law doctrine does not so much punish failures to keep promises as it creates an ability to make (legally enforceable) commitments on which people can (reasonably) rely (a similar view is argued in greater detail by Scanlon (Scanlon, Thomas M., "Promises and Contracts", in Benson, Peter (ed.), The Theory of Contract Law: New Essays, 2001, pp. 99-111; cf. Fried (Fried, Charles, Contract as Promise: A Theory of Contractual Obligation, cit., note 24, p. 13).

34 "As Lon Fuller and William Perdue pointed out ..., the fact that a person has promised to do something does not explain what should happen if he fails to do it." (Gordley, "Contract Law in the Aristotelian Tradition", in Benson, Peter (ed.), The Theory of Contract Law: New Essays, Cambridge, Cambridge University Press, 2001, pp. 265-334; footnote citing Fuller \& Perdue (Fuller, Lon L. and Perdue, William R. Jr., "The Reliance Interest in Contract Damages" (Parts I \& II), Yale Law Journal, vol. 46, 1936, pp 52-96, 373-420) omitted)

35 Barnett, Randy E., "A Consent Theory of Contract", Columbia Law Review, cit., note 1, pp. 269-321, and by the same author, "Some Problems with Contract as Promise", Cornell Law Review, vol. 77, 1992, pp. 1022-1033.

36 Barnett, Randy E., "Some Problems with Contract as Promise", Cornell Law Review, cit., note 35, p. 1027); see also Smith ("Towards a Theory of Contract", en Horder, Jeremy (ed.), Oxford Essays in Jurisprudence, cit., note 29).

37 Barnett, Randy E., "A Consent Theory of Contract", Columbia Law Review, cit., note 1, p. 270. 
The objection is that "consent" does little to explain what contract is, what should be enforced, how, and to what extent. What one basically has is "consent to contract" 38 thus consent does little of the work of determining the nature and scope of contract. 39

Reliance arguments try to construct a theory of obligation from the idea of reasonable reliance. ${ }^{40}$ The well-known difficulty here is that it is not easy to ground the "reasonableness" of one's reliance without some foundational notion of when someone should do what they have said they would do - some argument usually of promise and/or efficiency. ${ }^{41}$ Thus, reliance arguments seem to be derivative, grounded in another form of argument (promise-based or perhaps economic). Additionally, thinking of contractual obligations in terms primarily of reasonable reliance does not seem to match either the way most contracting parties view their interactions or the way that courts and doctrinal commentators discuss contract doctrine.

Law and economics theorists ${ }^{42}$ argue that most contract law doctrine can be explained as efforts to maximize the in-

38 Or, more precisely, consent to the transfer of rights or entitlements, or consent to the legal enforcement of such transfers (Barnett, Randy E., "A Consent Theory of Contract”, Columbia Law Review, cit., note 1, p. 303-305).

39 For another critique of consent theory, see Braucher (Contract Versus Contractarianism: The Regulatory Role of \Contract Law", Washington and Lee Law Review, vol. 47, 1990, pp. 703-706).

40 See Gilmore (The Death of Contract, cit., note 13); Atiyah (The Rise and Fall of Freedom of Contract, Oxford, Clarendon Press, 1979).

41 The critique is presented in greater detail in Barnett ("A Consent Theory of Contract”, Columbia Law Review, cit., note 1, pp. 274-276).

42 With most law and economics theorists, it is not so much that they have an economic theory of contract law - rather, they have a general theory of law (or, at least, of private law), which they hold to apply to Contract Law (as well as other areas) (e.g., Shavell, Foundations of Economic Analysis of Law, Cambridge, Mass., Harvard University Press, 2004). There is a growing list of detailed economically-based discussions of Contract Law, including Bolton \& Dewatripont (Contract Theory, Cambridge, Mass., MIT Press, 2005), Brousseau \& Glachant (The Economics of Contracts, Cambridge, Cambridge University Press, 2002), Craswell (e.g., "Contract Law: General Theories", in Boudewijn, Bouckaert and Gerrit Degeest (eds.), Encyclopedia of Law \& Economics, 2000), Edlin \& Schwartz ("Optimal Penalties in Contracts", Chicago Kent Law Review, vol. 78, 2003, pp. 33-54), Goetz \& Scott (e.g., "Liquidated Damages, Penalties, and the Just Compensation Principle: 
dividual and social gains from trade. ${ }^{43}$ This is often phrased in terms of the ability of parties to make a commitment on which another party can rely (R. Posner); 44 allowing parties to authorize or assent to state-enforced awards of expectation damages where performance is defective empowers parties to make such commitments. There are two standard criticisms of economic explanations of common law doctrines - that apply to all such theories (the critique may be most common in response to economic theories of tort law), but are certainly applicable to economic theories of contract law. First, economic theories fail as a matter of fit, in that a maximizing theory leaves out much of the participants' (judges', lawyers', and contracting parties') own understanding of what is going on in contract: that contract law does (or should) reflect foundational moral ideas about promises, agreements, and/or fairness, not just the consequentialist calculation. ${ }^{45}$ Second, there is a concern

Some Notes on an Enforcement Model of Efficient Breach", Columbia Law Review, vol. 77, 1977), Katz (e.g. "The Economics of Form and Substance in Contract Interpretation", Columbia Law Review, 2004), Kronman \& Posner (The Economics of Contract Law, Boston, Little, Brown and Company, 1979), E. Posner (e.g., "Contract Theory", in Golding, Martin P. and Edmundson, William A. (eds.), The Blackwell Guide to the Philosophy of Law and Legal Theory, Oxford, Blackwell Publishing, 2005, pp. 138-147), R. Posner (e.g., "Law and Economics - Contracts", IVR Encyclopaedia of Jurisprudence, Legal Theory, and Philosophy of Law, 2004, http://encyclopedia.ivr2003.net.), Schwartz (e.g. "Relational Contracts in the Courts: An Analysis of Incomplete Agreements and Judicial Strategies", Journal of Legal Studies, vol. 21, 1992, pp. 271-318), and Schwartz \& Scott ("Contract Theory and the Limits of Contract Law", Yale Law Journal, vol. 113, 2003, pp. 541-619).

43 As Craswell ("Two Economic Theories of Enforcing Promises", in Benson, Peter (ed.), The Theory of Contract Law: New Essays, Cambridge, 2001) has pointed out, it is important to understand that economic analysis of Contract Law has focused on which rules will create the optimal incentives and disincentives, not on when performance would be efficient.

44 Posner, Richard A., "Law and Economics - Contracts", IVR Encyclopaedia of Jurisprudence, Legal Theory, and Philosophy of Law, http://encyclopedia.ivr 2003.net.

45 E.g., Kraus ("Philosophy of Contract Law", en Coleman, Jules and Shapiro, Scott (eds.), The Oxford Handbook of Jurisprudence and Philosophy of Law, cit., note ); Smith (Introduction to Contract Theory, cit., note 33, pp. 132-136). Of course, to the extent that economic or efficiency theories are recharacterized as prescriptions for Contract Law rather than rational reconstructions, descriptions or explanations of (existing) Contract Law, the "fit" objection would fall away. 
that economic analysis may be too "flexible": able to offer a plausible explanation or justification of any doctrine (for any given rule, the rule and its opposite equally well). ${ }^{46}$ One prominent economic theorist, Richard Craswell, argued that economic analysis properly sees contract law as being about which rules created the optimal/efficient incentives for contracting (or potentially contracting) parties, but then listed eight different types of decisions, where the effect of any given rule might affect many at once, in ways that interact or may conflict (Craswell), ${ }^{47}$ resulting in overall consequences hard to predict (even under a simplified model). ${ }^{48}$

Relating to the criticisms of poor fit and conflicting incentives, one might consider the parallel to a critique of the economic explanation of tort law. The economic explanation of that area claims that the doctrinal rules create incentives for optimal levels of precaution for both the potential victim (and plaintiff) and the potential injurer (and defendant). However, as a number of theorists have pointed out (e.g., Coleman), ${ }^{49}$ the economic approach does not explain —as a corrective justice explanation would - the bilateral character of tort law: where negligent defendants make payments only to injured plaintiffs, and the amount of compensatory payments is set by the amount of damage proximately

46 See Korobkin ("Possibility and Plausibility in Law and Economics", Florida State University Law Review, vol. 32, 2005, pp. 781-795); cf. E. Posner ("Economic Analysis of Contract Law After Three Decades: Success or Failure?", Yale Law Journal, vol. 112, 2003, pp. 829-880). Some other criticisms of economic approaches are summarized by Benson ("Contract", in Patterson, Dennis (ed.), A Companion to Philosophy of Law and Legal Theory, Oxford, Blackwell, 1996, pp. 48-50).

47 Craswell, Richard, "Two Economic Theories of Enforcing Promises", in Benson, Peter (ed.), The Theory of Contract Law: New Essays, Cambridge, Cambridge University Press, 2001, pp. 26-32.

48 Craswell (ibidem, pp. 26-32) lists the following actions or decisions subject to incentives: to perform, to rely on the promised performance, to take interim precautions that will affect the ability to perform, the selection of parties with whom to transact (and at what price), how much time and effort to spend searching for better contracting partners, how carefully to evaluate the proposed transaction before committing to a promise, how much to tell the other party prior to performance; and the effect of enforceability on the allocation of risk.

49 Coleman, Jules, The Practice of Principle, Oxford, Oxford University Press, 2001, pp. 13-40. 
caused, rather than being based on the tortfeasor's level of negligence, as one might have expected had the objective been optimal deterrence. A similar critique could be grounded on the bilateral character of contract law: if contract were primarily about proper levels of incentives, it would not be clear why the payments should always go from breaching party to the party that was injured by the breach (rather than, say, to a state fund), and one might raise questions about remedial doctrines like mitigation and certainty, that can significantly affect the level of damages in ways unconnected to the appropriate level of (dis)incentives for defendants. 50

One could combine the different kinds of general theories in various ways: e.g., using an autonomy theory to justify the doctrinal areas and to set its basic parameters, while using an economic theory to select the more detailed rules. ${ }^{51}$ Of course, the different theories might also be "combined" in a different sense, if one saw them as having different objectives: e.g., a purely prescriptive autonomy theory as opposed to an explanatory or justificatory role for an economic theory. ${ }^{52}$

50 One can make an argument that mitigation is tied to the optimal level of incentives (regarding reliance) for the non-breaching parties, but that just adds to the general point that a bilateral structure of Contract Law will inevitably be in tension with trying to create the right level of incentives for both parties, as the optimal amount of damages to be paid by the defendant, to create the right incentives for future defendants, may not be the optimal level of payments to be received by the plaintiff, to create the right incentives for future plaintiffs.

51 See Kraus ("Reconciling Autonomy and Efficiency in Contract Law: The Vertical Integration Strategy", Philosophical Issues, cit., note 33); Oman ("Unity and Pluralism in Contract Law", Michigan Law Review, vol. 103, 2005, pp. 1483-1506); $c f$. Farber ("Economic Efficiency and the Ex Ante Perspective", in Kraus, Jody S. and Walt, Steven D. (eds.), The Jurisprudential Foundations of Corporate and Commercial Law, Cambridge, Cambridge University Press, 2000, pp. 54-86).

52 See Kraus ("Philosophy of Contract Law", en Coleman, Jules and Shapiro, Scott (eds.), The Oxford Handbook of Jurisprudence and Philosophy of Law, cit., note 33 , p. 689). Kraus also suggests that theories cannot usefully be compared where one takes doctrinal statements seriously and tries to explain them, while another theory focuses primarily on the outcome of cases, ignoring the conceptual distinctions internal to the practice (Kraus, idem). I would prefer to say that say that such theories still can be directly compared on a standard of explanatory efficacy, with the ability to incorporate the internal understanding one factor, and 


\section{THEORY MEETS PRACTICE}

For the commercial (contracting) practices of most modern countries, a simple analysis in terms of the morality of promising or the morality of enforcing fully voluntary exchanges will no longer be adequate. As other theorists have noted (e.g., Slawson), 53 conventional discussions of "meeting of the minds," "assent," and "freedom of contract" have unclear application (if they have any application at all) when a large proportion of the transactions entered into are based on agreements presented on standardized forms, not subject to negotiation, and where contract terms may be sent in the mail after purchase or placed on a separate website. (When software companies who want less regulation of their efforts to impose terms on consumers speak about protecting "the freedom of contract," they only unintentionally show us how far current contracting practices are from true mutual assent. 54

One commentator 55 has tellingly compared modern contracting practices to promising in advance to do whatever someone else has written in a sealed envelope. In some ways, this raises the problem well: one is offering a broad promise or assent, and like other alleged broad acts of consent, the moral and political question is how much weight a single promise can carry. A similar idea had been raised many decades back by Karl Llewellyn: that a party's acceptance (by action or otherwise) of an offer made on a stan-

perhaps an important factor, but not necessarily conclusive. In analytical legal philosophy, comparable arguments can be found, e.g., in the debates between inclusive legal positivism and exclusive legal positivism, and between the will theory of legal rights and the interests theory of legal rights; in each set of debates, at least one of the theories trades off fit with internal descriptions of the practice for some other meta-theoretical value.

53 Slawson, W. David, "Standard Form Contracts and Democratic Control of Lawmaking Power", Harvard Law Review, vol. 84, 1971, cit., note 11, pp. 529-566.

54 And the parallel with the "freedom of contract" analysis of Lochner v. New York, 198 U.S. 45 (1905) seems obvious.

55 Barnett, Randy E., "Consenting to Form Contracts", Fordham Law Review, vol. 71,2002 , pp. 635 у 636 . 
dard form should be understood as assent to the dickered terms (quantity, price, and perhaps delivery and warranty) and a "blanket assent" to all other not unreasonable terms. 56

There are other contexts where moral and political theorists refer to a statement or action giving broad assent to a wide range of obligations. The most prominent example is the argument that by voting, receiving state benefits, or not leaving the country one takes on the obligation to obey a country's laws - usually stated more precisely as a prima facie obligation to obey laws from a generally just legal system. (e.g., Higgins). ${ }^{57}$ One could see this as a parallel to the Llewellyn view: that one agrees to abide by not unreasonable laws (laws from generally just legal systems that are not themselves clearly immoral). The predominant - though by no means universal- view among political and legal theorists is that such actions are not adequate to ground a general moral obligation to obey the law. ${ }^{58}$

One can of course press that point even more strongly. Even express promises to obey the law (such as the oaths the legal officials frequently must offer) likely have limits in the moral obligations they create. If the law one is asked to uphold or apply is egregiously unjust, there is at least a strong countervailing moral reason not to obey the law, which may override one's moral obligation to keep a promise to obey the law.

Some might argue that the obligation to obey the law example is too extreme - mostly because Barnett's original image of promising to do everything written in a sealed en-

56 See Llewellyn (The Common Law Tradition: Deciding Appeals, Boston, Little, Brown, 1960, pp. 362-371); a similar conclusion is reached by Barnett ("Consenting to Form Contracts", Fordham Law Review, cit., note 55); cf. Leff ("Contract as Thing", American University Law Review, vol. 19, 1970, pp. 131-157).

57 Higgins, Ruth C. A., The Moral Limits of Law: Obedience, Respect, and Legitimacy, Oxford, Oxford University Press, 2004.

58 See, e.g., Edmundson, The Duty to Obey the Law: Selected Philosophical Readings, Lanham, Maryland, Rowman \& Littlefield, 1999; and by the same author, "The Duty to Obey the Law", Legal Theory, vol. 10, 2004, pp. 215-259); Higgins (The Moral Limits of Law: Obedience, Respect, and Legitimacy, cit., note 57). 
velope is itself an (intentional) exaggeration of the situation with form contracts. There is likely to be significant consumer ignorance of the terms in form contracts - because the terms of inaccessible or incomprehensible, or because consumers choose (perhaps rationally) not to read the whole document. However, this level of party ignorance may be little different than the level of party ignorance (or, if one prefers different terminology, "asymmetric information") in many other sorts of transactions. As Barnett argues (elsewhere within the same article with the "sealed envelope" argument), "contract law is itself one big form contract that goes unread most of the time" (Barnett). 59 That is, most people enter such legal relationships without knowing many (perhaps nearly all) of the important background rules regarding formation, performance, and remedies. 60

All of this leads back to the basic question: to what extent do parties have a moral obligation to comply with all the terms in the agreements to which they have assented in some way? And what consequences should follow for the government's role in regulating agreements?

\section{RETHINKING CONTRACT LAW}

What happens when the ideal construct at the core of one's theory about a practice diverges so much from the practice that it distorts more than it explains? And what happens when the practices diverge so much from any sort of ideal that one can doubt the moral or policy legitimacy of

59 Barnett, Randy E., "Consenting to Form Contracts", Fordham Law Review, cit., note 55, p. 644 .

60 Similar points have been made about marriage (e.g., L. Baker: "II Think I Do": Another Perspective on Consent and the Law", Law, Medicine \& Health Care, vol. 16,1988 , pp. 256-260; and by the same author, "Promulgating the Marriage Contract", Journal of Law Reform, vol. 23, 1990, pp. 217-264), and about the purchase of information goods (Alexander, "Trouble on Track Two: Incidental Regulations of Speech and Free Speech Theory", Hastings Law Journal, vol. 44, 1993, pp. 936-938). 
(at least certain aspects of) the practice? There may come a point when theorists of a practice should no longer be focusing on adjustments or applications at the margin, and should return to first principles, to rethink the entire enterprise. And it may be that this point has come (again) for contract law, or at least for some categories of contracting practice. Something approximating a political justification must be offered, at least as a supplementary theory, regarding the enforcement, or selective enforcement, of the agreements where one cannot speak (except as a legitimating fiction) of fully informed, fully voluntary assent to all terms.

In rethinking this area of law, one likely starting place is to distinguish among agreements, focusing on the nature of the parties and the topic of the agreement. For example, Alan Schwartz \& Robert Scott ${ }^{61}$ have argued that a different set of rules should apply to commercial contracts entered between large businesses than when the party alignment is different (e.g., where one party is a consumer or small business, or non-commercial agreements between intimates). As Schwartz \& Scott point out, many of the factors raising questions about enforcement of agreements (or the moral obligation to comply with agreements) are less present in commercial transactions between large business entities. On one hand, large business entities are likely less subject both to bounded rationality and to exploitative pressures than are consumers or individuals contracting within intimate relationships. Also, autonomy considerations are absent for businesses, and therefore different sets of rules may be justified for inter-business transactions compared to transactions involving individuals. ${ }^{62}$

61 Schwartz, Alan and Scott, Robert E., "Contract Theory and the Limits of Contract Law", Yale Law Journal, cit., note 42, pp. 541-619.

62 For an argument rejecting Schwartz \& Scott's conclusion that autonomy considerations do not apply to inter-business transactions, see Oman ("Corporations and Autonomy Theories of Contract: A Critique of the New Lex Mercatoria", Denver University Law Review, forthcoming, 2005). 
Even as regards consumer agreements, Richard Craswell ${ }^{63}$ has warned against a too-quick conclusion that certain contractual agreements or contractual terms should not be enforced because one party's assent was less than fully voluntary. Craswell points out that the regulatory alternatives to enforcing agreements where there has been less than fully voluntary consent (because of inadequate information or insufficient alternatives) are either refusal to enforce the agreement at all or judicial imposition of alternative terms that the court finds to be reasonable. Neither alternative solves the problem of consent or autonomy, but at best replaces one set of imposed terms for another. And whether the judicially imposed terms will be better (fairer or "better" under some other criterion) than the party-imposed, and party-acquiesced, terms will depend on judgments of relative competence that may vary across different fact situations.

Also, when one moves to mandatory terms (a likely response/remedy to the problems discussed here, as will be seen below), there are obvious problems from the perspective of the seller/lessor/more powerful party: first, that it clearly has not assented to those terms; and second, that the reality of the market may make not dealing at all preferable to dealing on the required terms.

The idea of moving away from a promissory or freedom of contract ideal for thinking about contractual obligations is certainly not new. To some extent, all of the efforts to understand contract law generally or particular contract law doctrines from within a law and economics perspective are grounded on a broadly consequentialist analysis (whether understood as wealth-maximizing, welfare maximizing, or utilitarian). ${ }^{64}$ Also noteworthy are the arguments that the line between contract law and tort law has disappeared -

63 Craswell, Richard, "Property Rules and Liability Rules in Unconscionability and Related Doctrines", University of Chicago Law Review, cit., note 20, pp. 1-65.

64 See generally Kronman \& Posner (The Economics of Contract Law, cit., note 42); Shavell (Foundations of Economic Analysis of Law, cit., note 42, pp. 289-385). 
or will soon, or should soon (Atiyah, 65 Gilmore66); and the analysis that looks at the adhesion contracts of large companies as being (from the perspective of consumers) a kind of private legislation that should accordingly be regulated in some way. 67

If one were to try to justify something like the status quo in contract law, one would likely offer an argument along the line suggested by law and economics (whether one characterizes that argument as wealth-maximizing, welfare-maximizing, or utilitarian). Under this analysis, the question is whether it will probably maximize social wealth (or welfare or utility) to enforce agreements even where it is likely that at least one of the parties may not have considered or read all of the terms, and even where some of the terms may be harmful or create externalities. This is certainly a tenable approach, that should be considered seriously, especially given the value of predictability for much of commercial discourse.

The issue is how far the consequentialist analysis will go. It is of course possible that enforcing all one-sided terms, regardless of how unlikely they are to be read, how unexpected, or how one-sided, will in fact maximize social wealth (or welfare or utility). However, it is also possible - and, to many people, more likely - that refusal to enforce at least some of those terms is the rule that would have the better results tested under a maximizing standard. ${ }^{68}$ At the same time, as already discussed, a judge facing a case of not-fully-volun-

65 Atiyah, P. S., The Rise and Fall of Freedom of Contract, cit., note 40.

66 Gilmore, Grant, The Death of Contract, cit., note 40.

67 Kessler, Friedrich, "Contracts of Adhesion - Some Thoughts About Freedom of Contract”, Columbia Law Review, vol. 43, 1943, pp. 629-642.

68 The problem with consequentialist analyses (utilitarian, welfarist, or wealth-maximizing) is that the real-world costs and benefits for most inquiries quickly become so intricate that it usually is pure speculation to claim that the ultimate bottom-line figure is positive or negative. Additionally, the well-known tendencies for people to misjudge badly both the likelihood of an event and its value (e.g., Kahneman, Daniel et al. (eds.) Judgment under Uncertainty: Heuristics and Biases, Cambridge, Cambridge University Press, 1982) may undermine the normative justification underlying economic prescriptions (that people are in the best position to judge what will be in their own long-term interests). 
tary assent to terms may not necessarily be able to develop and impose better terms than the parties could themselves. ${ }^{69}$ However, this important caveat still is a far step from assuming that whatever terms a party assents to in some way are the optimal terms to enforce.

\section{The Moral Obligation to Keep Contracts}

While there is a lively literature about whether there is a moral obligation to obey the law generally (e.g., Edmundson), ${ }^{70}$ there is not much discussion about whether we $^{71}$ have a moral obligation to keep our contracts. ${ }^{72}$ I use the awkward term "keep," because there are doctrinal problems with speaking of an obligation to perform one's con-

69 Craswell, "Property Rules and Liability Rules in Unconscionability and Related Doctrines", University of Chicago Law Review, cit., nota 20.

70 Edmundson, William A. (ed.), The Duty to Obey the Law: Selected Philosophical Readings, cit., nota 58; The Duty to Obey the Law", Legal Theory, cit., note 58, pp. 215-259.

71 Much of the discussion in this section assumes human contracting parties. The reality of modern contracting, that much of it is done between corporations (and other entities) raises complications. Can one speak of the moral obligations of corporations to keep promises? (or of respecting the autonomy of corporations?) Nor is it clear that this complication can be resolved simply by shifting the focus to the people who run, or act in the name of corporations and other entities. See Kraus ("Philosophy of Contract Law", en Coleman, Jules and Shapiro, Scott (eds.), The Oxford Handbook of Jurisprudence and Philosophy of Law, cit., note 33, p. 696 n.20); Rakoff ("Contracts of Adhesion: An Essay in Reconstruction", Harvard Law Review, vol. 96, 1983, p. 1236).

72 The debate about the nature and ground of the moral obligation to keep promises is substantial, and largely beyond the scope of this paper. One classical source is Hume (A Treatise of Human Nature, 2nd. ed., L. A. Selby-Bigge and P. H. Nidditch (eds.), Oxford, Clarendon Press (originally published 1739), 1978, Book III, section V, at pp. 516-525). Significant recent work includes Kolodny \& Wallace ("Promises and Practices Revisited", Philosophy \& Public Affairs, vol. 31, 2003, pp. 119-154), Murphy (Promise and Practice" (unpublished manuscript), 2003), Pratt ("Scanlon on Promising", Canadian Journal of Law and Jurisprudence, vol. 14, 2001, pp. 143-154), Scanlon ("Promises and Practices", Philosophy and Public Affairs, vol. 19, 1990, pp. 199-226; "Promising", in Craig, E. (ed.), Routledge Encyclopedia of Philosophy, London, Routledge, 1998, http://www.rep.routledge.com/arti cle/L1 18; "Promises and Contracts", in Benson, Peter (ed.), The Theory of Contract Law: New Essays, cit., note 33). A provocative rethinking of the relationship of promising and contract is offered by Shiffrin ("The Divergence of Contract and Promise", Harvard Law Review, vol. 120, 2007, pp. 708-753). 
tracts (even if we confine the discussion to contracts where one does not have a doctrinal justification for not performing - e.g., based on misrepresentation, mutual mistake, or duress). As Oliver Wendell Holmes, Jr., famously pointed out, one's (legal) obligation under a valid contract (under American law) is not to perform, but either to perform or to pay damages. ${ }^{73}$ There are exceptional circumstances where a contracting party could obtain an equitable order of specific performance, ordering a breaching party to perform, but these are rare. ${ }^{74}$ The fact that parties not only can, but in a sense, should breach where they could do better by breaching, paying damages, and taking advantage of an alternative opportunity, is summarized as the idea of "efficient breach". ${ }^{75}$ The fact that contract law carries a strict li-

73 Holmes ("The Path of the Law", Harvard Law Review, vol. 10, 1897, p. 462; by the same author, in DeWolfe Howe, Mark (ed.), The Common Law, Boston, Little Brown \& Co., 1963, p. 236); cf. R. Posner (Economic Analysis of Law, 6th. ed., New York, Aspen Publishers, 2003, pp. 118-132). Holmes here discounts the difference between the primary obligation to perform, and the damages to be paid for failure of performance. To the Holmesian "bad man" (Holmes, "The Path of the Law", Harvard Law Review, pp. 460 y 461), there may no such difference, though to those who take their obligation to perform as promised seriously, there will be.

For an argument that Holmes should not be understood as a supporter of "efficient breach", see Perillo, Joseph M., "Misreading Oliver Wendell Holmes on Efficient Breach and Tortious Interference", Fordham Law Review, vol. 68, 2000, pp. 1085-1106.

74 Though, where one is dealing with agreements for which specific performance might be available as a matter of course, such as the purchase of land or the purchase of a unique good (UCC § 2-716(1)), then one might reasonably speak of a legal obligation to perform the agreement (and not just to perform or pay damages), and perhaps, derivatively, a moral obligation to perform.

The idea that an equitable order of specific performance should only be given where money damages are inadequate can be traced to the struggles between the Common Law courts and the Chancery courts (Simpson, A History of the Common Law of Contract, Oxford, Clarendon Press, 1975, pp. 595-598). In modern times, the doctrine can be justified either by the view that the parties would reasonably have understood that the promisor would not be held to perform where an alternative performance was easily available (e.g., Gordley, "Contract", in Patterson, Dennis (ed.), A Companion to Philosophy of Law and Legal Theory, Oxford, Blackwell, 1996 , pp. 17 y 18) or an efficiency argument that equitable remedies given as a matter of course could too often lead to needless transaction costs, hold-ups and/or economic waste in performance (Posner, R., Economic Analysis of Law, cit., note 73 , pp 131 y 132).

75 E.g., Goetz \& Scott ("Liquidated Damages, Penalties, and the Just Compensation Principle: Some Notes on an Enforcement Model of Efficient Breach", Colum- 
ability standard (there are few acceptable "excuses" for non-performance), and that punitive damages are not available for egregious or badly motivated breaches of contracts, ${ }^{76}$ echoes and reinforces this attitude of contract law: that it is amoral, and focuses only on the compensation of parties' economic losses. In line with the above discussion, Richard Craswell 77 suggests helpfully that one might distinguish between "an obligation to perform" a promise and an "obligation to perform-or-pay-damages," with the second being the one most relevant to discussions of modern (American) contract law. ${ }^{78}$

A second complication: after a regime of contract law enforcement has been set up, one's moral obligations regarding an agreement may be different from what they were before, at least if the legal regime is generally just. For the existence of the working regime may create claims of reasonable reliance that were not present before. ${ }^{79}$ And the fact that under American contract law rules (and the rules of every other comparable regime in other jurisdictions with which I am familiar) makes some, but not all, promises legally enforceable, adds to the complication. While I will ini-

bia Law Review, cit., note 42), Craswell ("Contract Remedies, Renegotiation, and the Theory of Efficient Breach", Southern California Law Review, vol. 61, 1988), Friedmann ("The Efficient Breach Fallacy", Journal of Legal Studies, vol. 18, 1989, pp. 1-24).

76 There is a small category of contracts where punitive damages are allowed, but these cover a small number (and idiosyncratic selection) of agreements. Restatement (Second) of Contracts $\S 353$ \& Comment a. For a good overview of the reasons for excluding emotional distress recovery for the vast majority of contracts, see Erlich v. Menezes, 21 Cal. 4th. 543, 981 P.2d 978, 87 Cal. Rptr. 886 (1999).

77 "Two Economic Theories of Enforcing Promises", in Benson, Peter (ed.), The Theory of Contract Law: New Essays, cit., note 43, p. 27.

78 Scanlon, Thomas M., "Promises and Contracts", in Benson, Peter (ed.), The Theory of Contract Law: New Essays, cit., note 33, p. 107.

79 However, it is also worth noting that research consistently shows that individuals' perceptions of how parties should act in the performance of agreements tends to deviate significantly from what contract doctrine prescribes (and that individuals' knowledge of contract doctrine tends to be faulty) (e.g., Macaulay, Stewart, "Non-Contractual Relations in Business: A Preliminary Study", American Sociology Review, vol. 28, 1963, pp. 55-67; Collins, Hugh, Regulating Contracts, Oxford, Oxford University Press, 1999, pp. 129-137). 
tially focus on the moral obligation that may exist independent of the legal regime of enforcement, the factor of institutional enforcement must eventually be added to the analysis.

For our purposes, the hardest question might be whether or when an obligation to keep contracts or to perform promises is altered by limitations on the parties' knowledge or alternatives. For Thomas Scanlon, who analyzes the question within a general contractualist conception of moral obligation, the issue is whether potential promisors could reasonably reject a principle that bond them to keep promises or keep contracts despite limitations on alternatives and information. 80 While the answer seems to be "yes," at least for significant limitations, Scanlon adds that we must then inquire about whether potential promisees could reasonably reject a rule that would allow promisors to void or evade their promises under such circumstances. ${ }^{81}$ It seems likely that potential promisors and promisees (especially if they come from relatively distinct groups, like consumers and large businesses) are unlikely to come to consensus on what types of limitations would excuse obligation (It is also worth noting that for Scanlon, the "reasonableness" of objections tends to do a lot of work). ${ }^{82}$

One could imagine a very different sort of contract law system, one that paralleled tort law, in generally imposing obligations not for all damage-causing actions and omissions, but only for those which fall below some acceptable standard, and are therefore called "faulty." However, that is not the standard that we have. In part, the "strict liability" standard is properly justified on the basis that it serves

80 Scanlon, Thomas M., "Promises and Contracts", in Benson, Peter (ed.), The Theory of Contract Law: New Essays, cit., note 33, pp. 111-117.

81 Ibidem, pp. 115 y 116.

82 For example, for Scanlon, it is the basis on which we would refuse a robber's objection to not being paid money promised under physical coercion, but not refuse a physician's objection to not being paid money promised under coercion of circumstances (Scanlon, Thomas M., "Promises and Contracts", in Benson, Peter (ed.), The Theory of Contract Law: New Essays, cit., note 33, p. 115). 
commercial interests (by increasing the predictability that either performance will be rendered or comparable payments made by way of damages).

Another part of the justification for the current system is that it remains in the parties' hands to set their own standards for full compliance and for actionable conduct. ${ }^{83}$ Just as parties can put in their agreements terms excusing non-performance where buyer is unable to obtain a mortgage or where the vendor's performance is made extremely difficult by some "act of God," so the parties could insert provisions that would excuse any category of "non-faulty" non-performance they were able to articulate.

One should, of course, note that whatever the freedom of contracting the parties have, it remains significant that the baseline is for strict performance. 84

\section{IMPLICATIONS FOR GOVERNMENT REGULATION}

Even if we could ground a fairly skeptical or critical account regarding the moral obligation to comply with agreements one has entered, the consequences are not immediately obvious.

First, we must be careful not to (too quickly) equate an analysis of a contracting party's moral obligation with what the state should do regarding contracts. Consider the analogy — suggested earlier - with the moral obligation to obey the law. A number of prominent theorists have argued that there is no general moral obligation to obey the law, 85 but

83 This was recognized at least as long ago as the famous case of Paradine v. Jane, 82 Eng. Rep. 897 (K.B. 1647), where the court justified a strict liability standard by stating: "when the party by his own contract creates a duty or charge upon himself, he is bound to make it good, if he may, notwithstanding any accident or inevitable necessity, becauase he might have provided against it by his contract". Id. at 897-898.

84 One should also note that there are some limits on party freedom of contract (e.g., as regards liquidated damages, or agreements to authorize equitable remedies).

85 E.g., Raz, Ethics in the Public Domain, Oxford, Clarendon Press, 1994, pp. 325-338); Kramer (In Defense of Legal Positivism, Oxford, Oxford University Press, 
these theorists have not argued that it therefore follows (morally speaking or otherwise) societies should not set up legal systems. The conclusion that citizens may not have a general or presumptive obligation to obey the laws - even the generally just laws of a generally just legal systemdoes not entail that governments morally should desist from promulgating laws. Under modern thinking, the questions of what legitimate governments should do, and what citizens should do in response to the actions of those governments, are held to be divergent, if overlapping, questions. Similarly, the question of whether one should (morally speaking) keep all of one's contracts may differ from whether governments ought to enforce them. 86

Second, and this is a related point, there are good moral and policy reasons (some of them discussed earlier) for enforcing at least some of the agreements where the contracting parties' consent might be defective. Among the standard arguments here are the importance of predictability of enforcement, 87 the difficulty of proving (or disproving) questions of consent, avoiding incentives to stay ignorant or to lie about one's knowledge, and so on.

Third, as mentioned above, concluding that party assent was less than fully voluntary is only the beginning of the inquiry. There is no reason to believe that, for all cases, that refusing enforcement of such agreements is the best outcome (however "best outcome" is understood), or that judges or legislators will always do better than parties even parties with limited knowledge and limited alternatives - in choosing terms to govern commercial interactions. ${ }^{88}$

1999, pp. 254-308); Higgins (The Moral Limits of Law: Obedience, Respect, and Legitimacy, cit., note 58).

86 To the extent that one accepts a sharp "principle v. policy" distinction, here the governmental "ought" might be thought to be a policy conclusion rather than a purely moral one (that is, one more of maximizing social welfare rather than protecting individual rights or doing what justice requires).

87 Especially for a market economy where investments may depend on agreements being both assignable and predictably enforceable.

88 Véase las obras del siguiente autor, Craswell, Richard, "Property Rules and Liability Rules in Unconscionability and Related Doctrines", University of 
Fourth, it is often far from clear that regulation will solve the underlying problem. While it may be unreasonable (e.g.) for licensors of software or sellers of computer hardware not to make contractual terms available ahead of time (e.g., by posting on a website), or not to give notice (e.g., during telephone or store transactions) that there will be additional terms "in the box," how much will be achieved by an alternative rule, forcing notice and disclosure? It seems likely that the percentage of consumers who actually read (and understand) the contractual terms will not rise that much, however much legal and moral concerns about "due notice" will be assuaged.

\section{Note ON Rights AND REMEDIES}

The relation between rights and remedies is a perennial one, ${ }^{89}$ but that one may need to be revisited (if briefly, and with no ambition that such a brief discussion could resolve the issue, or even add significantly to ongoing debate) for the purpose of this discusssion.

Jurists under both Roman Law and medieval English law "started life with a list of transactions which were actionable through the procedural forms within which they had to work, rather than with a general principle of accountability". 90

Chicago Law Review, cit., nota 20, pp. 1-65; id., "Remedies When Contracts Lack Consent: Autonomy and Institutional Competence", Osgoode Hall Law Journal, vol. 33, 1995, pp. 209-235); id., "Two Economic Theories of Enforcing Promises", in Benson, Peter (ed.), The Theory of Contract Law: New Essays, cit., nota 43, pp. 38 y 39.

89 For a recent contribution, made in the context of discussing contract law, see Friedmann ("Rights and Remedies", in Cohen, Nili and Mckendrick, Ewan (eds.), Comparative Remedies for Breach of Contract, Oxford, Hart Publishing, 2005, pp. 3-17).

90 Simpson (A History of the Common Law of Contract, cit., nota 74, p. 186). He adds: "Indeed for most purposes it was not in the least necessary that they should do more" (id., 187). 
Peter Stein ${ }^{91}$ has located an important part of the origin of our modern ideas about legal rights in the work of Hugo Donellus. Prior to Donellus, the legal analysis in the Roman Law tradition involved the combination of a fact-situation with the remedy the legal system granted under those facts. ${ }^{92}$ Donellus spoke instead in broader, more abstract terms, of the plaintiff having a right that grounded his or her claim to a remedy.

In a sense, my argument in this Article seems a step backward: away from general rights and back towards thinking of law as granting specific remedies to a pleaded combination of facts. As earlier noted, I am not alone in this view: in particular, I am following a basic lesson of the American legal realists - that it is an error to view a legal right abstracted from the remedy the legal system will make available for its violation (e.g., Llewellyn). ${ }^{93}$

To say that one has a (contractual) right means different things depending on what kind of remedy one can receive in court for that right: specific performance, full compensation for one's expected benefit, a small fraction of that expectation (as when damages are severely reduced due to doctrines like mitigation ${ }^{94}$ and certainty). ${ }^{95}$

91 Stein, Peter, "Donellus and the Origins of the Modern Civil Law", in Ankum, J. A. et al. (eds.), Mélanges Felix Wubbe, Friboug, Switzerland, University Press Fribourg, 1993, pp. 439-452.

92 See also Gordley ("Natural Law Origins of the Common Law of Contract", in Barton, John (ed.), Towards a General Law of Contract, Berlin, Duncker \& Humblot, 1990, pp. 371: "Roman law was a law of particular contracts, each with its own rules as to when it become binding"). Of course, what was true of Roman law was, if anything, more true of the medieval English writ system: where particular remedies were available tied to a plaintiff's ability to fit the claim within quite specific parameters.

93 Llewellyn, Karl N., "Some Realism About Realism - Responding to Dean Pound", Harvard Law Review, vol. 44, 1931, p. 1244.

94 Thus, if one has a fixed number of items to sell, and more buyers than items, then a breach of an agreement to purchase may yield only minor, incidental damages (cf. Murray, Murray on Contracts, 4th. ed., Newark, N.J., LexisNexis, 2001, § 122 , at $802-803)$.

95 One sub-category of uncertainty/speculation that is in some jurisdictions treated as a per se rule holds that new businesses will not be allowed to claim lost profits; however, some jurisdictions now allow plaintiffs in such cases to at least 
One might point out that the remedy available for a given set of facts is often uncertain prior to court determination (and that there were periods in the history of contract law where the jury's determination of damages was relatively unconstrained by rules or judicial oversight. 96 This does not prove any general conclusion, but is an important point to be incorporated: that the nature of a legal right may entail significant uncertainty as to what one could recover for breach.

One need not deny that, at the level of general moral and legal theory, there is a point to thinking about rights as separate from their associated duties and remedies. Thinking of rights separately from duties and remedies helps to emphasize the way that rights can be the justification (in policy discussions or judicial opinions) for new duties and remedies. ${ }^{97}$ However, I think that insight does not foreclose a closer association of right with remedy in one's theorizing about a substantive area of law, like contract law.

\section{GENERAL THEORY}

There is an abundance of books and articles offering the (or "a") theory of contract law. ${ }^{98}$ Theories of contract law commonly discuss a single principle (e.g., promise, consent, reliance, or efficiency) which is said to explain all of contract law, both for this country and for other countries (and perhaps for all time). Rather than add one more general theory to the pile, this Article has offered a narrower and

try to show their lost profits with sufficient certainty (Murray, Murray on Contracts, cit., nota 94, § 121, at 792 and 793).

96 Simpson, A. W. B., A History of the Common Law of Contract, cit., note 74, pp. 549-551.

97 Raz, Joseph, The Morality of Freedom, Oxford, Clarendon Press, 1986, pp. 170 y 171.

98 E.g., Fried (Contract as Promise: A Theory of Contractual Obligation, cit., note 33), Barnett ("A Consent Theory of Contract", Columbia Law Review, cit., note 1), Benson "The Unity of Contract Law", in Benson, Peter (ed.), The Theory of Contract Law: New Essays, Cambridge, Cambridge University Press, 2001, pp. 118-205), Smith (Introduction to Contract Theory, cit., note 33). 
more cautious view of contract law, focusing more on the rules of a single time and place, and denying that any single principle can explain the whole field.

The idea of contract law as a special category is relatively recent. ${ }^{99}$ The idea of a general theory of contract law (or any other area of law) might well derive from the view that law can and should be viewed systematically, or even "scientifically". One finds this approach in England only in the late 18th and early 19th century, with the earliest legal treatises (and John Austin's development of legal positivist theories of law). 100 The civil law countries had a longer and more established history of treatise writing and other systematic works about areas of law ${ }^{101}$ (from which the English treatise writers apparently borrowed liberally), ${ }^{102}$ and there is also the Natural Law tradition, which supported the idea that there might be general principles that did or should underlie the chaos of legal decisions. ${ }^{103}$

99 See, e.g., Simpson (Simpson, A. W. B., "Innovation in Nineteenth Century Contract Law", Law Quarterly Review, vol. 91, 1975; by the same author, A History of the Common Law of Contract, cit., note 74); Ibbetson (A Historical Introduction to the Law of Obligations, Oxford, Oxford University Press, 1999); J. H. Baker ("Origins of the "Doctrine" of Consideration, 1535-1585", in Morris S. Arnold et al. (eds.), On the Laws and Customs of England: Essays in Honor of Samuel E. Thorne, Chapel Hill, University of North Carolina Press, 1981, pp. 336-358).

100 See Simpson ("Innovation in Nineteenth Century Contract Law", Law Quarterly Review, cit., note 99, pp. 247-278; 1981, pp. 267 y 268). Ibbetson writes (A Historical Introduction to the Law of Obligations, cit., note 99, p. 215): "Before 1700 the English law of contract had developed without any articulated theory to support it”.

On Austin, and the development of systematic thinking about positive law, see Bix (Jurisprudence: Theory and Context, 4th. ed., London, Sweet \& Maxwell, 2006, pp. 33-36).

101 In Germany, much of the important work of thinking systematically, and theoretically, about contract law and other private law areas, occurred in the 16th. century (e.g., Berman, Law and Revolution II: The Impact of the Protestant Reformations on the Western Legal Tradition, Cambridge, Mass., Harvard University Press, 2003, p. 158).

102 Simpson, A. W. B., "Innovation in Nineteenth Century Contract Law", Law Quarterly Review, cit., note 99, pp. 254-257.

103 Simpson ("Innovation in Nineteenth Century Contract Law", Law Quarterly Review, cit., note 99, p. 255); see also Ibbetson (A Historical Introduction to the Law of Obligations, cit., note 99, pp. 217-219). For an overview of Natural Law theory, see, e.g., Bix ("Natural Law: The Modern Tradition", in Coleman, Jules and 
Where a project purports to be about the theory of contract law, it seems useful to take a moment to figure out what might be meant by that. Theorizing about social practices and social institutions can be descriptive, prescriptive, or something in-between. As it turns out, most discussions of "theories" of areas of law tend mostly to be in that amorphous "in-between" area, as will be discussed in greater detail below.

(Theories further along the scale towards pure prescription are certainly possible, though they do not entirely escape the meta-theoretical difficulties we will find with theories that focus on explanation or justification of existing practices. Whether describing, interpreting, or prescribing, the theorist must face the question of whether the entire complex practice can be explained or reformed in terms of a single principle or value - likely contrary to a good portion of actual current practice; if not, the theorist must find a way to construct an overarching theory that contains some basis for reconciling or balancing multiple values. ${ }^{104}$ This text will focus on theories whose primary purpose is explanation or justification, not prescription.)

I want to consider the nature of "philosophical foundation" explanations, distinguishing them from prescriptive theories and other forms of descriptive theories. "Philosophical Foundations of the Common Law" is an approach exemplified both in courses of that name (including a famous such course at Oxford University), and in books and arti-

Shapiro, Scott (eds.), The Oxford Handbook of Jurisprudence and Philosophy of Law, Oxford, Oxford University Press, 2002, pp. 61-103).

104 Kraus ("Philosophy of Contract Law", en Coleman, Jules and Shapiro, Scott (eds.), The Oxford Handbook of Jurisprudence and Philosophy of Law, cit., note 33, pp. 687 y 688 n.1) Kraus's own suggestion elsewhere (Kraus, "Reconciling Autonomy and Efficiency in Contract Law: The Vertical Integration Strategy", in Sosa, Ernest and Villanueva, Enrique (eds.), Philosophical Issues, 11, Social, Political, and Legal Philosophy, cit., note 33), in the context of a discussion of rational reconstruction theories, is that different theories might be "vertically integrated" by giving each distinctive "tasks": e.g., that an autonomy theory might justify the existence and general outline of a contract law system, but that particular rules within the area might be chosen on efficiency grounds. A similar suggestion is made by Oman ("Unity and Pluralism in Contract Law", Michigan Law Review, cit., note 51). 
cles that attempt to elucidate "the basic nature" of a particular common law subject 105 or an important legal concept common to a number of common law areas. ${ }^{106}$ Philosophical foundation theories are generally similar to the "rational reconstructions" familiar to legal doctrinal writers, in the sense that they mean to give the best justification and re-characterization possible of a given doctrine or area while remaining true to the actual practice and the case results (they could also be considered similar to Dworkin's "constructive interpretation"). ${ }^{107}$

In Dworkin's work, the rational reconstruction ("constructive interpretation") is part of a distinctive theory, in which it is of the nature of law that what it (currently) requires can only be determined by a process of this sort. 108 For those who do not accept Dworkin's view of law, the motivation for or justification of rational reconstruction (or philosophical foundations) may be a little harder to discern - it certainly is not always made explicit. Within common law countries at least, rational reconstruction might be justified on the ground that it mimics the process of accepted legal/judicial reasoning, at least in common law cases. ${ }^{109}$

Whatever the value generally of rational reconstruction at the level of doctrinal development and advocacy, one might question when and whether such reconstructions are useful at a more general or abstract level. Sometimes philosophical foundations theories are presented as being an ex-

105 E.g., in tort law (Owen, Philosophical Foundations of Tort Law, cit., note 24; Postema, Philosophy and the Law of Torts, Cambridge, Cambridge University Press, 2001), property law (e.g., Penner, The Idea of Property in Law, Oxford, Clarendon Press, 1997), criminal law (Moore, "A Theory of Criminal Law Theories", Tel Aviv University Studies in Law, cit., note 2), and contract law (Benson, The Theory of Contract Law. New Essays, Cambridge, Cambridge University Press, 2001).

106 E.g., causation (Hart and Honoré, Causation in the Law, 2nd. ed., Oxford, Clarendon Press, 1985).

107 Dworkin, Ronald, Law's Empire, cit., note 3, pp. 49-53.

108 Dworkin (Law's Empire, cit., note 3) would apply a similar approach to understanding the meaning of a work of art or the requirements of (many) social practices besides law.

109 They also mimic the way law tends to be taught, at least in the United States. 
BRIAN BIX

planation of individual doctrinal rules or whole areas of doctrine.

One needs to keep in mind the different sort of activities that go under the name of "explanation" (which noting that the boundary lines between the objectives are often blurred). There can be historical or causal theories of an area of law, descriptive theories, and normative or evaluative theories. ${ }^{110}$

In this context, it is important to keep in mind alternative forms of explanation too often ignored or discounted in philosophical foundation discussions: that the development of certain common law doctrines may be due primarily to certain historical contingencies, rather than reflecting any deep moral or policy justification. ${ }^{111}$ Within contract law a historical explanation may well be superior to alternative (morality-based or economics-based) explanations for a number of matters, including the doctrine of consideration and for some of the remedies rules. Here, though, "explanation" is causal - why we have the doctrines we do- rather than justificatory.

Also, among rational reconstructions, one might distinguish those that put greater emphasis on the "explanation" (description, plus some element of prediction), as against those that place greater emphasis on justification. Jody Kraus ${ }^{112}$ has usefully shown how economic theories of contract law tend to fall into the first group, while deontic (au-

110 Moore, Michael S., "A Theory of Criminal Law Theories", Tel Aviv University Studies in Law, cit., note 2.

111 See, e.g., Gordon (Gordon, "Using History in Teaching Contracts: The Case of Britton v. Turner", Hawai'i Law Review, vol. 26, 2004, pp. 424-434); cf. Simpson (A History of the Common Law of Contract, cit., note 74); Stoljar (A History of Contract at Common Law, Canberra, Australian National University Press, 1975). For a good example of historical explanation (in competition with philosophical explanation), from tort law, see Calabresi ("Supereditor or Translator: Comments on Coleman", in Bix, Brian (ed.), Analyzing Law, Oxford University Press, 1998, pp. 113 y 114).

112 Kraus, Jody S., "Philosophy of Contract Law", The Oxford Handbook of Jurisprudence and Philosophy of Law, Coleman, Jules and Shapiro, Scott (eds.), cit., note 33 , pp. 687-751. 
tonomy, promise-based) theories of contract law tend to fall into the second group.

My primary focus will be the (largely undiscussed) problem confronting philosophical foundations: given that different legal systems often have quite different rules (in every relevant area - contract law, tort law, criminal law, property law, etc.), why should we assume, as most discussions in this area do, that we are dealing with a single and unitary topic when we talk about "(the philosophical foundation of) contract law"? A variety of possible responses (conceptual, Platonic, prescriptive) will be considered. The variety of contract law will be considered by reference to materials in comparative law and legal history, with special emphasis on the European legal systems, and also on the international principles found in the Convention on Contracts for the International Sale of Goods (CISG) (e.g., Lookofsky) ${ }^{113}$ and the UNIDROIT Principles (Farnsworth). ${ }^{114}$ No legal system does (and likely no legal system could) enforce all promises or all exchanges. A basic question for any legal system is the criteria it uses to determine which promises or exchanges it will enforce and which it will not. Noting the disparate criteria offered on the one hand by Common Law systems (based on the doctrine of consideration and some supplementary doctrines) and, on the other hand, by some of the Continental legal systems (which have somewhat different criteria, e.g., the "cause" of French and German law), ${ }^{115}$ will display both some of the diversity among different Contract Law systems as well as some of the underlying unities. Additionally, a basic cleavage will be seen between those systems whose doctrinal and remedial

113 Lookofsky, Joseph, Understanding the CISG in the USA, 2nd. ed., The Hague, Kluwer Law International, 2004.

114 Farnsworth, E. Allan, "An International Restatement: The UNIDROIT Principles of International Commercial Contracts", University of Baltimore Law Review, vol. 26, 1987, pp. 1-7.

115 See, e.g., Marsh (Comparative Contract Law, England-France-Germany, Aldershot, Gower, 1994, pp. 95-111); cf. Gordley ("Contract Law in the Aristotelian Tradition", in Benson, Peter (ed.), The Theory of Contract Law: New Essays, cit., note 34). 
rules strongly encourage performance of contracts (e.g., by general availability of specific performance remedies, 116 or by granting compensation for intentional breach of contract) and those systems (e.g., the American system) which generally treat performance and the payment of (purely compensatory) damages as equally acceptable. Even the ability of winning parties to gain their attorney's fees from the losing party - though this may be a rule of private litigation generally rather than a rule of contract law in particular-117 will necessarily affect the nature of contract law (by affecting the ability of parties to be fully compensated for breach on one hand, and by creating strong disincentives to enforcement suits on the other). ${ }^{118}$

116 But $c f$. Lando \& Rose ("On the Enforcement of Specific Performance in Civil Law Countries", International Review of Law and Economics, vol. 24, 2004, pp. 473-487), where the authors offer evidence that specific performance is becoming an increasingly rare remedy in Denmark, Germany and France, and they relate this trend to the administrative costs of running a system where specific performance is an available and attractive alternative remedy.

117 Cf. Zapata Hermanos Sucesores, S.A. v. Hearthside Baking Company, Inc., 313 F.3d 385 (7th. Cir. 2002) (refusing to grant attorney's fees as general damages in a CISG action, in part because rules regarding prevailing parties' right to such fees is a general rule rather than a rule of contract law).

Smith ("Towards a Theory of Contract", en Horder, Jeremy (ed.), Oxford Essays in Jurisprudence, cit., note 29, p. 123; Introduction to Contract Theory, cit., note 33, pp. 103-105) suggests that we look at Contract Law only as the rules creating and defining rights, with the remedial rules seen as part of another area of law, probably tort law. In Zapata, supra, Judge Posner similarly states that "no one would say that French contract law differs from U.S. because the winner of a contract suit in France is entitled to be reimbursed by the loser, and in the U.S. not. Zapata, 313 F.3d at 388. I respectfully disagree with Prof. Smith and Judge Posner (though I am not disagreeing with the outcome in Zapata), preferring the legal realist insight that one cannot understand the nature of a (contractual) right separate from the remedies that are available to protect it.

118 Even seemingly smaller differences might have significant effects on one's view of a contract law system: e.g. whether breaching parties (who did not meet a standard of "substantial performance") should be able to sue for restitutionary compensation, compare Lancellotti v. Thomas, 491 A.2d 117 (Pa. Super. Ct. 1985) (applying the Restatement standard allowing recovery) with Mechanical Piping Services, Inc. v. Jayeff Construction Corp., 626 N.Y.S.2d 547, 547 (2d Dept. 1995) (following the classical common law rule that no recovery is allowed); whether damages for emotional distress should be available at least in classes of commercial contracts where they are reasonably foreseeable, compare Erlich v. Menezes, 21 Cal.4th. 543, 981 P.2d 978, 87 Cal.Rptr.2d 886 (1999) (reaffirming general US rule of no emotional distress damages for breach of contract in a case involving faulty 
The alternative position suggested here is that contract theory should focus on a single legal system at a particular period of time; thus, there should usually be different theories for different countries (though how different each country's theory would be would depend on how divergent the rules and practices are).

To have a theory of contract law assumes that there is a single entity "contract law" to have a theory about. In one sense, this is trivially true: almost every American law school (and many schools outside the United States) has a course called "contract law"; 119 there are a large number of casebooks and treatises purporting to discuss "contract law"; and the American Law Institute created two different "Restatements" of contract law, the most recent in 1979. The fact that legal materials can be conveniently categorized together for the purpose of teaching a course or writing a textbook may give some evidence of a unity sufficient to ground a general theory. Additionally, one might note that though there are certainly differences in the rules in different jurisdictions, there is also a great deal of similarity, more than one might expect from historical accident. This point should not be discounted, and theorists should consider possible sources of convergence. One might look to the influence of particular approaches - the Roman Law approach for civil law countries which consciously built from

construction of a house) with Farley v. Skinner, [2001] 3 W.L.R. 899 (H.L.) (allowing non-pecuniary damages for sale of house case where object of entire contract was to give pleasure, relaxation or peace of mind); whether promissory estoppel can ground a cause of action or is only available to prevent enforcement of existing rights, compare Restatement (Second) of Contracts § 90(1) (promissory estoppel cause of action) with Combe v. Combe [1951] 2 K.B. 215 (under English law, reliance on the promise no basis for enforcing the promise); and whether there is a general common law requirement of good faith and fair dealing (in cases other than the sale of goods cases covered by UCC, art 2), see Subaru of Am., Inc. v. David McDavid Nissan, Inc., 84 S.W.3d 212, 225-26 (Tex. 2002) (Texas as one of the few states to deny that there is an obligation of good faith for non-UCC cases).

119 Though there are also many transactions that look like contracts, but that tend to be dealt with in courses other than contract law courses (e.g., the treatment of leases and sales of property primarily in property law and real estate transaction courses, and the discussion of premarital and separation agreements primarily in family law courses). 
that model, and the English approach for countries that were once had colonial ties or other significant ties to England. Other arguments explaining convergence might be more functional: that contract law converges where it becomes clear that a certain set of rules works best in responding to (common) economic problems and pressures. Nonetheless, while the similarities should be taken into account in any theoretical discussion, this text will conclude that theories focused on the doctrinal rules of particular legal systems are still to be preferred to general, universal or "conceptual" theories of contract law.

Michael Moore has suggested that contract law might be thought of as a "functional kind" - a collection of all the rules that have the function of "getting people to keep their promissory obligations, obligations that are distinct from the non-promissory obligations dealt with by criminal law and torts". ${ }^{120}$ It might be possible to maintain this view of the "functional kind" contract law, while still noting the problems (discussed earlier) of a promise-based theory of contract law, though there are obvious tensions with trying to assert both simultaneously.

The larger question remains as before: whether focusing on the what is common among all these different forms of transactions, while down-playing what is distinct, creates more insight than distortion.

\section{General Contract Law}

One might concede that contract law theory should be focused on a particular legal system (or at least on connected legal systems, like England, the United States and the Commonwealth countries, whose contract law systems developed from common roots), but still believe that a general

120 Moore, Michael S., "A Theory of Criminal Law Theories", Tel Aviv University Studies in Law, cit., nota 2, p. 131, footnote omitted; p. 132) offers that there are some areas of law (he suggests administrative law as an example) that are neither functional kinds nor natural kinds, but just arbitrary collections of topics. 
contract law theory is appropriate within that particular system or group of systems. Using the example of American contract law, this Section will argue that the diversity within a single contract law system is usually too great to justify a general theory of contract law, in which one or two principles explain or justify the entire doctrinal area.

Contract law discussions too frequently begin from the assumption that there is a single theory or approach that is appropriate for everything that falls under the rubric "contract" (This may in fact be the appropriate conclusion at the end of the day, but it is a dubious point to take for granted). The basic question is whether different kinds of agreements are subject to different theories of obligation. Are there basic differences, from the perspective of contract law theory, between (e.g.) commercial transaction between merchants, simple exchanges between individuals, and prenuptial agreements setting property rights at divorce?121

In many jurisdictions, there are areas of contract law, defined by subject matter, which carry distinctive rules (special rules of formation, mandatory terms, performance, or remedies): e.g., landlord-tenant, employment contracts, charitable pledges, construction contracts, franchise agreements, pension promises, and insurance agreements. ${ }^{122}$ (While noting the diversity of categories, and the distinctive rules and principles that often go with them, one must, of

121 Schwartz \& Scott ("Contract Theory and the Limits of Contract Law", Yale Law Journal, cit., note 42) argue that the set of contract rules that apply to good-sized businesses dealing commercially with one another can and should differ from the contract rules applied in other contexts - e.g., when one of the parties is a consumer, or when two individuals are entering a marriage-related agreement (a comparable argument is offered by Farber ("Economic Efficiency and the Ex Ante Perspective", in Kraus, Jody S. and Walt, Steven D. (eds.), The Jurisprudential Foundations of Corporate and Commercial Law, Cambridge, Cambridge University Press, pp. 54-86). The argument is that many of the factors that justify certain protective rules do not apply when discussing the commercial dealings of firms: cognitive biases, protection from overreaching, protection of autonomy interests, etcetera.

122 At least one casebook teaches contract law in a way that emphasizes the different rules for different kinds of agreements (Macaulay et al., Contracts: Law in Action, 2nd. ed., Newark, LexisNexis, vols. I and II, 2003) (I am told that many of the contract law textbooks from a generation or two back were similarly organized). 
course, also be aware of a contrary theoretical error, of taking such nominalism too far). ${ }^{123}$ A different sort of division might be suggested, based on the process preceding formation: distinguishing, for example, between agreements that are the result of detailed negotiation, and "adhesion contracts" (agreements entered on the forms of the more sophisticated and more powerful party, offered on a take-itor-leave-it basis).

To some extent, mainstream contract thinking, if not mainstream contract theorizing, recognizes the fact of diversity, for the Restatement (Second) of Contracts itself recognizes forms of recovery (promissory estoppel, §90, and promissory restitution, $\S 86$ ) other than those based on breach of contract; and most contract law courses include not only those alternative grounds of recovery, but also some discussion of unjust enrichment claims arising from contract-like interactions. ${ }^{124}$ Recognition of the fact and significance of diversity may also be indicated by the way that certain categories of contracts (e.g., insurance policies, landlord-tenant agreements, premarital contracts) are subject to separate regulation (by statute, agency regulation, and/or case-law). ${ }^{125}$

One could, of course, argue that forms of action that deviate too much from core contract law examples (however one defines them) simply should be understood as "not contract". While this is in principle a legitimate move, one must

123 The Supreme Court once notoriously commented: "We deal here with the [constitutional] law of billboards". Metromedia, Inc. v. City of San Diego, 453 U.S. 490, 501 (1981).

124 E.g., Farnsworth (Contracts, 4th. ed., New York: Aspen Publishers, 1999, § 2.20, at 101-108; Knapp Charles L. et al., Problems in Contract Law: Cases and Materials, 5th ed., New York, Aspen Publishers, 2003, pp. 116-146).

125 Additionally some theorists offer arguments that there are categories of law that are usually considered separate from contract law that should be more properly treated as a subset of contract (e.g., corporate law as a nexus of contracts (Easterbrook, Frank H. and Fischel, Daniel R., "The Corporate Contract", Columbia Law Review, vol. 89, 1989, pp. 1416-1448). Also, negotiable instruments, mortgages, and secured transactions, are usually taught in separate courses, though such transactions would seem to be, or to have similarities with, contracts. 
be careful that a theory is not made true simply by exiling all contrary evidence. ${ }^{126}$

Michael Moore ${ }^{127}$ has nicely summarized the motivations of theorizing at the level of areas of law: that it is in part entailed by the moral requirement that we treat like cases alike; that it helps to determine the proper outcome in novel cases, and it is entailed by our assumption -or hope- that the law coherently pursues worthy objectives. These are important moral (and psychological) forces pushing us towards having a general theory for an area of law, but it may be that some areas are too various and inconsistent to ground a general theory, despite those reasons for theory. ${ }^{128}$

\section{XI. "Contract” AND "LAW"}

In some ways, the question of whether one can or should have a theory about "contract law" generally parallels the question of whether there can and should be a single theory about the nature of "law".

As contract law is a subset of Law, it is not surprising that a similar analysis might apply to both. For example, both are social products, and thus seem less obvious candidates for theories of their nature than natural kinds like "gold". And, for both, there would likely be resistance to a claim that the social practices were instantiations of some

126 See, e.g., Kraus ("Philosophy of Contract Law", en Coleman, Jules and Shapiro, Scott (eds.), The Oxford Handbook of Jurisprudence and Philosophy of Law, cit., note 33, pp. 706 n. $38 \& 716-717$, discussing Fried); Oman ("Unity and Pluralism in Contract Law", Michigan Law Review, cit., note 51, criticizing Smith).

127 Moore, Michael S., "A Theory of Criminal Law Theories", Tel Aviv University Studies in Law, cit., note 2; and by the same author "Theories of Areas of Law", San Diego Law Review, cit., note 42.

128 In Moore ("A Theory of Criminal Law Theories", Tel Aviv University Studies in Law, cit., note 2), the author discusses considerations regarding a general theory of criminal law. My text does not deny the possibility, value, or persuasiveness of theories of doctrinal law generally - it focuses only on contract law- and I think that there are good reasons to believe that other areas of law (perhaps criminal law, perhaps tort law) are better candidates for general theories than contract law is. However, I leave that for others to show. 
Platonic "Idea". It is at least tenable that whatever sorts of arguments ground conceptual arguments or general theories at the level of the nature of law would also ground such theories and arguments at the level of doctrinal areas (and vice versa). ${ }^{129}$

Joseph Raz"130 has argued that "law" is a part of a community's collective self-understanding. Whatever the merits of that claim, it would seem significantly more tenable than a comparable claim that "contract" or the doctrines of contract law were an integral part of our communal self-understanding. ${ }^{131}$

The three major challenges to a unitary general theory of law are: (1) that conceptual theory has no place to play in jurisprudence (or elsewhere in philosophy); and that it should be replaced by a naturalist/empirical analysis (see Leiter);132 (2) that there is no single "[our] concept of law" sufficiently precise or agreed upon to ground such a theory (cf. Bix);133 or (3) (a somewhat different point) that there are a number of competing alternative theories of law, selection among which requires a moral or political argument 134

129 Cf. Zipursky ("Pragmatic Conceptualism in Jurisprudence", unpublished manuscript, 2005), arguing for applying his "pragmatic conceptualism" both to theories of tort law and to general jurisprudence.

130 Raz, Joseph, "On the Nature of Law," Archiv für Rechts- und Sozialphilosophie, vol. 82, 1996, pp. 1-25; Raz, Joseph, "Can There Be a Theory of Law?", in Golding, Martin P. and Edmundson, William A. (eds.), The Blackwell Guide to the Philosophy of Law and Legal Theory, Oxford, Blackwell Publishing), 2005, pp. 324-342.

131 There are other important views about conceptual analysis (e.g., Zipursky, "Pragmatic Conceptualism", Legal Theory, vol. 6, 2000, pp. 457-485; "Pragmatic Conceptualism in Jurisprudence", unpublished manuscript), but it is not clear why or how any of them would justify a significantly different response to the challenge presented here - the argument that the variety of practices within and across jurisdictions makes any attempt to create an overarching theory of contract law unlikely to succeed.

132 Leiter, Brian, "Beyond the Hart/Dworkin Debate: The Methodology Problem in Jurisprudence", American Journal of Jurisprudence, vol. 48, 2003, pp. 17-51.

133 Bix, Brian, "Raz on Necessity", Law and Philosophy, vol. 22, 2003, pp. 537559.

134 The contrary view (see Coleman, The Practice of Principle, cit., note 49, pp. 197-210; Kramer, In Defense of Legal Positivism, cit., nota 85, pp. 239-253) is that the basis for selection is theoretical/explanatory rather than moral/political. 
(Perry). ${ }^{135}$ It appears that all three lines of argument might be equally raised against a general theory of contract law.

In raising doubts about general theories of contract law, it is not that anyone doubts that there are rules about which agreements and promises will be enforced by state norms and state institutions. And most would concede that these rules have a certain intellectual coherence (within limits), and some stability over time. Additionally, there are obvious similarities between the rules that are applied to promises and agreements in different states of the United States; and some, if frequently weaker, similarities between the rules applied in the United States and in other countries. However, the question is whether these points of convergence are sufficiently numerous and levels of coherence sufficiently strong to justify a single general theory. Nonetheless, as has been argued in this Article, there remain too much divergence within and among Contract Law to justify a general and universal theory of contract. ${ }^{136}$

\section{Consequences}

The basic position of this Article has been that there is no general or universal theory of contract law. Assuming that

135 Perry, Stephen R., "Interpretation and Methodology in Legal Theory", in Marmor, Andrei (ed.), Law and Interpretation, Oxford, Clarendon Press, 1995, pp. 97-135; Perry, Stephen R., "Hart's Methodological Positivism”, Legal Theory, vol. 4, 1998, pp. 427-467.

136 In coming to a similar conclusion, Nigel Simmonds argues that general theories of private law areas are simply efforts to overcome the dissensus and compromises in doctrinal areas by rising to a sufficiently vague and abstract principle. Simmonds argues that this misses the significance of what is going on in the doctrinal areas:

"The ability of private law to occupy an area of convergence between diverse moral theories without clearly articulating any one such theory, and without levitating to a plane of abstraction remote from the resolution of concrete disputes, may be the very feature that makes private law a significant element in those structures that make dissensus tolerable" (Simmonds, "The Possibility of Private Law", in Tasioulas, John (ed.), Law, Values and Social Practices, Aldershot, Dartmouth, 1997, p. 137). 
this is correct, what would follow. Michael Moore ${ }^{137}$ has pointed out the beneficial role general theories can play in guiding judicial decision-making and in making the area of law fairer (in the sense of being more consistent across cases). Some of this may be lost when there is no general theory for all of (American) contract law, but I think the loss would be modest, given that one could (and should) still have theories of areas of/within contract law.

\section{Note on Proving a Negative}

In this Article, I have argued that there is no single general and universal theory of contract law. In a sense, this involves an assertion of a negative - that a particular truth does not exist, or a particular approach will not work- and it is well known that proving a negative is a difficult task.

In certain unusual sets of circumstances, it might be possible to show that an alternative is conceptually or logically impossible, but there is no reason to believe that contract law theory is one of those unusual sets of circumstances. All that is available is to present the arguments for why a narrower and more particular theory of law will be superior to the likely general and universal theory alternatives.

And one cannot rely simply on asserting that the other side of the argument (here, supporting a general and universal theory of Contract Law) has the burden of proof and has not met it. 138 One must show that one's own alternative (or class of alternatives) is better than what is being rejected. I hope that I have at least begun to make that showing.

137 Moore, Michael S., "A Theory of Criminal Law Theories", Tel Aviv University Studies in Law, cit., nota 2; and by the same author, Theories of Areas of Law", San Diego Law Review, cit., nota 2, pp. 731-741.

138 I recognize that there may be places in the text where such an argument from burden of proof might seem to be implied. I disown any such line of argument, and apologize for any place where the text appears to imply it. 


\section{CONCLUSION}

An overarching theory of contract law (or even, of American or Mexican contract law), presented as a rational reconstruction grounded on autonomy, would likely have to be rejected for its failures to explain the detailed rules of contract law and for its poor fit with the enforcement of many far-from-fully-voluntary agreements. On the other hand, economic/consequentialist theories would likely fare little better, as they do not adequately take into account the doctrinal terms in which parties, judges, and advocates understand contract; also, the claim of these theories to explain the details of contract law results is undermined by doubts about the falsifiability of the efficiency explanations offered.

The Article has raised issues relating to the divergence between theory and practice. For a large number of contracts, especially those entered by consumers when dealing with large businesses, characterization of the transaction in terms of "a meeting of minds" or "freedom of contract" so far deviates from what is actually going on as to be unhelpful and distorting. Legal scholars (and other commentators) have known this for a long time, but the consequences have not been fully worked out or worked through. At a minimum, one might suspect that teaching and talking about contracts (both in law school classes, and more generally) as if they were normally the result of person-to-person negotiations between parties of comparable sophistication, knowledge and bargaining power, when that is not the case, might have the effect of giving a level of legitimacy to contracts that some significant subset of them may not deserve. The fact that, at least with consumer contracts, many terms are simultaneously unlikely to be read, are not brought to the attention of the parties, and are substantively one-sided, may justify government-imposed terms (or 
at least default terms that can only be overcome with clear evidence of knowing waiver) (Korobkin). ${ }^{139}$

Skepticism about the tenability of a single unified theory for contract law is hardly new. ${ }^{140}$ However, given the number of prominent theorists who propose or defend general theories of contract law, it is an issue worth revisiting. Given the significant diversity of rules and approaches, both between different countries (and even, to some extent, among different states of the United States), and within a particular jurisdiction between different types of agreements, it seems difficult to believe that a single overarching theory can have explanatory value that outweighs whatever distorting effects it would inevitably have. ${ }^{141}$

Of course, even if it is true that one should not construct general theories about contract law, and that the proper focus is the contract law of a particular legal system (at a particular time), this does not mean that the theory for one system's contract law will be of no use in discussing the contract law of different legal systems. Another legal system's contract law theory is particularly likely to be valu-

139 Korobkin, "Bounded Rationality, Standard Form Contracts, and Unconscionability", University of Chicago Law Review, vol. 70, 2003.

140 Recent exponents of similar views include Robert Hillman ("The Crisis in Modern Contract Theory", Texas Law Review, vol. 67, 1988, pp. 103-136), Jean Braucher ("Contract Versus Contractarianism: The Regulatory Role of \Contract Law", Washington and Lee Law Review, vol. 47, 1990, pp. 701, n. 14), Dennis Patterson ("An Open Letter to Professor James Gordley", Wisconsin Law Review, vol. 1991, pp. 1432-1436), Larry DiMatteo ("The Norms of Contract: The Fairness Inquiry and the "Law of Satisfaction" - A Nonunified Theory", Hofstra Law Review, vol. 24, 1995, pp. 349-454), James Gordley ("Contract", in Patterson, Dennis (ed.), A Companion to Philosophy of Law and Legal Theory, Oxford, Blackwell, 1996, pp. 3-20), Nigel Simmonds ("The Possibility of Private Law", in Tasioulas, John (ed.), Law, Values and Social Practices, cit., note 33 ), Nathan Oman ("Unity and Pluralism in Contract Law", Michigan Law Review, cit., note 51), Leib ("On Collaboration, Organizations, and Conciliation in the General Theory of Contract Law", Quinnipiac Law Review, vol. 24, 2005, pp. 1-23), and DiMatteo (et al., Visions of Contract Theory: Rationality, Bargaining, and Interpretation, Oxford, Hart Publishing, 2006). Randy Barnett ("The Richness of Contract Theory", Michigan Law Review, vol. 97, 1999, pp. 1413-1429) has characterized such skepticism as characteristic of an earlier generation too attached to legal realism.

141 This is not to say that the label and category "contract law" cannot continue to serve a purpose in creating a convenient collection of topics of workable size for law school courses and legal treatises. 
able where the two systems have a common historical origin (as with England and the United States), or where the developments in one system are considered influential by officials and commentators in the other (as among the Commonwealth countries).

The focus of this Article has been to offer a theory localized to a particular country, the United States, ${ }^{142}$ at a particular time (the early years of the 21 st. century), and often "localized" further, with theories that focused on particular areas of doctrine, or even specific doctrinal rules. However, it will be important to discover the extent to which the local focus must be tempered by an understanding of more general principles, general purposes or general tendencies that may cause different sets of rules and principles to converge.

XV. BIBLIOGRAPHY

ALEXANDER, Larry A., "Trouble on Track Two: Incidental Regulations of Speech and Free Speech Theory", Hastings Law Journal, vol. 44, 1993.

AMERICAN LAW INSTITUTE, "Principles of the Law of Software Contracts", Council Draft, num. 1, November 7, 2006.

ATIYAH, P. S., The Rise and Fall of Freedom of Contract, Oxford, Clarendon Press, 1979.

BAKER, J. H., "Origins of the "Doctrine" of Consideration, 1535-1585", in MORRIS S., Arnold et al. (eds.), On the Laws and Customs of England: Essays in Honor of Samuel E. Thorne, 1981, Chapel Hill, University of North Carolina Press.

An Introduction to English Legal History, 4th. ed., Londres, Butterworths, 2002.

142 With the possibilities that aspects of this theory would need to be adjusted as one moved between state jurisdictions, to the extent that the state laws varied sufficiently. 
BAKER, Lynn A., "II Think I Do": Another Perspective on Consent and the Law", Law, Medicine \& Health Care, vol. 16, 1998.

- - "Promulgating the Marriage Contract", Journal of Law Reform, vol. 23, 1990.

BARneTt, Randy E., "A Consent Theory of Contract", Columbia Law Review, vol. 86, 1986.

_-, "Some Problems with Contract as Promise", Cornell Law Review, vol. 77, 1992.

_- "The Sound of Silence: Default Rules and Contractual Consent", Virginia Law Review, vol. 78, 1992.

- "The Richness of Contract Theory", Michigan Law Review, vol. 97, 1999.

- "Consenting to Form Contracts", Fordham Law Review, vol. 71, 2002.

BeBCHuK, Lucian A. and Posner, Richard A., "One-Sided Contracts in Competitive Consumer Markets", Michigan Law Review, vol. 104, 2006.

Benson, Peter, "Contract", in PATterson, Dennis (ed.), A Companion to Philosophy of Law and Legal Theory, Oxford, Blackwell, 1996.

(ed.), The Theory of Contract Law. New Essays, Cambridge, Cambridge University Press, 2001.

-, "The Unity of Contract Law", in BEnson, Peter (ed.), The Theory of Contract Law: New Essays, Cambridge, Cambridge University Press, 2001.

BERMAN, Harold J., Law and Revolution II: The Impact of the Protestant Reformations on the Western Legal Tradition, Cambridge, Massachussets, Harvard University Press, 2003.

BIX, Brian, "Natural Law: The Modern Tradition", in COLEMAN, Jules and SHAPIRO, Scott (eds.), The Oxford Handbook of Jurisprudence and Philosophy of Law, Oxford, Oxford University Press, 2002. 
—, "Raz on Necessity", Law and Philosophy, vol. 22, 2003.

- Jurisprudence: Theory and Context, 4th. ed., London, Sweet \& Maxwell, 2006.

Bolton, Patrick and Dewatripont, Mathias, Contract Theory, Cambridge, Massachussets, MIT Press, 2005.

BOUCKAERT, Boudewijn and DE GEest, Gerrit (eds.), (19962000) Encyclopedia of Law and Economics, http: encyclo.findlaw.com (Edward Elgar and University of Ghent).

BRAUCHER, Jean, "Contract Versus Contractarianism: The Regulatory Role of \Contract Law", Washington and Lee Law Review, vol. 47, 1990.

Brousseau, Eric and Glachant, Jean-Michel (eds.), The Economics of Contracts, Cambridge, Cambridge University Press, 2002.

CALABRESI, Guido, "Supereditor or Translator: Comments on Coleman", in BIX, Brian (ed.), Analyzing Law, Oxford University Press, 1998.

Coleman, Jules, The Practice of Principle, Oxford, Oxford University Press, 2001.

Collins, Hugh, Regulating Contracts, Oxford, Oxford University Press, 1999.

CRASWELL, Richard, "Contract Remedies, Renegotiation, and the Theory of Efficient Breach", Southern California Law Review, vol. 61, 1988.

, "Contract Law, Default Rules, and the Philosophy of Promising”, Michigan Law Review, vol. 88, 1989.

—-, "Property Rules and Liability Rules in Unconscionability and Related Doctrines", University of Chicago Law Review, vol. 60, 1993.

—_, "Remedies When Contracts Lack Consent: Autonomy and Institutional Competence", Osgoode Hall Law Journal, vol. 33, 1995. 
- "Contract Law: General Theories", in BoudEwIJN, Bouckaert and GERRIT, Degeest (eds.), Encyclopedia of Law \& Economics, Cheltenham, UK, Edward Elgar, vol. 3, 2000, and http://allserv.rug.ac.be/ gdegeest/ 4000book.pdf.

_- "Against Fuller and Perdue", University of Chicago Law Review, vol. 67, 2000.

_-, "Two Economic Theories of Enforcing Promises", in BEnSOn, Peter (ed.), The Theory of Contract Law: New Essays, Cambridge, Cambridge University Press, 2001.

DiMatTeO, Larry A., "The Norms of Contract: The Fairness Inquiry and the "Law of Satisfaction" - A Nonunified Theory", Hofstra Law Review, vol. 24, 1995.

- et al., Visions of Contract Theory: Rationality, Bargaining, and Interpretation, Oxford, Hart Publishing, 2006.

Dworkin, Ronald, Law's Empire, Cambridge, Massachussets, Harvard University Press, 1986.

EASTERBROOK, Frank H. and Fischel, Daniel R., "The Corporate Contract", Columbia Law Review, vol. 89, 1989.

EdLIn, Aaron S. and SchwARTZ, Alan, "Optimal Penalties in Contracts", Chicago Kent Law Review, vol. 78, 2003.

EDMUNDSON, William A. (ed.), The Duty to Obey the Law: Selected Philosophical Readings, Lanham, Maryland, Rowman \& Littlefield, 1999.

- , "The Duty to Obey the Law", Legal Theory, vol. 10, 2004.

FARBER, Daniel A., "Economic Efficiency and the Ex Ante Perspective", in KRAUS, Jody S. and WALT, Steven D. (eds.), The Jurisprudential Foundations of Corporate and Commercial Law, Cambridge, Cambridge University Press, 2000. 
FARNSWORTH, E. Allan, "An International Restatement: The UNIDROIT Principles of International Commercial Contracts", University of Baltimore Law Review, vol. 26, 1987.

- Contracts, 4th. ed., New York, Aspen Publishers, 1999.

FEInMAN, Jay M., "Un-Making Law: The Classical Revival in the Common Law", Seattle University Law Review, vol. 28, 2004.

FINNIS, John, Natural Law and Natural Rights, Oxford, Clarendon Press, 1980.

FRIED, Charles, Contract as Promise: A Theory of Contractual Obligation, Cambridge, Massachussets, Harvard University Press, 1981.

FRIEDMANN, Daniel, "The Efficient Breach Fallacy", Journal of Legal Studies, vol. 18, 1989.

-, "Rights and Remedies", in COHEN, Nili and MCKENDRICK, Ewan (eds.), Comparative Remedies for Breach of Contract, Oxford, Hart Publishing, 2005.

Fuller, Lon L. and PERDUe, William R., Jr., "The Reliance Interest in Contract Damages" (Parts I \& II), Yale Law Journal, vol. 46, 1936.

GILMORE, Grant, The Death of Contract, Columbus, Ohio, Ohio State University Press, 1974.

Goetz, Charles J. and ScotT, Robert E., "Liquidated Damages, Penalties, and the Just Compensation Principle: Some Notes on an Enforcement Model of Efficient Breach", Columbia Law Review, vol. 77, 1977.

GORDLEY, James, "Natural Law Origins of the Common Law of Contract", in BARTON, John (ed.), Towards a General Law of Contract, Berlin, Duncker \& Humblot, 1990.

- The Philosophical Origins of Modern Contract Doctrine, Oxford, Clarendon Press, 1991. 
- "Contract", in PATTERson, Dennis (ed.), A Companion to Philosophy of Law and Legal Theory, Oxford, Blackwell, 1996.

"Contract Law in the Aristotelian Tradition", in Benson, Peter (ed.), The Theory of Contract Law: New Essays, Cambridge, Cambridge University Press, 2001.

- (ed)., The Enforceability of Promises in European Contract Law, Cambridge, Cambridge University Press, 2001.

GORDON, Robert W., "Using History in Teaching Contracts: The Case of Britton v. Turner", Hawai'i Law Review, vol. 26, 2004.

HART, H. L. A. and Honoré, Tony, Causation in the Law, 2nd. ed., Oxford, Clarendon Press, 1985.

Helmholz, Richard H., "Assumpsit and Fidei Laesio", Law Quarterly Review, vol. 91, 1975.

- "Contracts and the Common Law", in BARTON, John (ed.), Towards a General Law of Contract, Berlin, Duncker and Humblot, 1990.

HigGins, Ruth C. A., The Moral Limits of Law: Obedience, Respect, and Legitimacy, Oxford, Oxford University Press, 2004.

Hillman, Robert A., "The Crisis in Modern Contract Theory", Texas Law Review, vol. 67, 1988.

Holmes, Oliver Wendell, Jr., "The Path of the Law", Harvard Law Review, vol. 10, 1897.

- The Common Law, in DEWolfe Howe, Mark (ed.), Boston, Little Brown \& Co., 1963.

Hume, David, A Treatise of Human Nature, in SElby-BIGGe, L. A. and NiDDITCH, P. H. (eds.), 2nd. ed., Oxford, Clarendon Press, 1978 (originally published 1739).

IBBETSON, David J., "Consideration and the Theory of Contract in Sixteenth Century Common Law", in 
BARTON, John (ed.), Towards a General Law of Contract, Berlin, Duncker \& Humblot, 1990.

- A Historical Introduction to the Law of Obligations, Oxford, Oxford University Press, 1999.

KAHNEMAN, Daniel et al. (eds.), Judgment under Uncertainty: Heuristics and Biases, Cambridge, Cambridge University Press, 1982.

KATZ, Avery Wiener, "The Economics of Form and Substance in Contract Interpretation", Columbia Law Review, vol. 104, 2004.

KESSLER, Friedrich, "Contracts of Adhesion - Some Thoughts About Freedom of Contract", Columbia Law Review, vol. 43, 1943.

KNAPP, Charles L. et al., Problems in Contract Law: Cases and Materials, 5th. ed., New York, Aspen Publishers, 2003.

Kolodny, Niko and Wallace, R. Jay, "Promises and Practices Revisited", Philosophy \& Public Affairs, vol. 31, 2003.

KorobKIN, Russell, "Behavioral Economics, Contract Formation, and Contract Law", in CASS R., Sunstein (ed.), Behavioral Law and Economics, Cambridge, Cambridge University Press, 2000.

- - "Bounded Rationality, Standard Form Contracts, and Unconscionability", University of Chicago Law Review, vol. 70, 2003.

- "Possibility and Plausibility in Law and Economics", Florida State University Law Review, vol. 32, 2005.

KrAMER, Matthew, In Defense of Legal Positivism, Oxford, Oxford University Press, 1999.

KRAUS, Jody S., "Reconciling Autonomy and Efficiency in Contract Law: The Vertical Integration Strategy", in Sosa, Ernest and Villanueva, Enrique (eds.), Philo- 
sophical Issues, 11: Social, Political, and Legal Philosophy, Boston, Blackwell Publishers, 2001.

"Philosophy of Contract Law", in COLEMAN, Jules and SHAPIRO, Scott (eds.), The Oxford Handbook of Jurisprudence and Philosophy of Law, Oxford, Oxford University Press, 2002.

"Legal Theory and Contract Law: Groundwork for the Reconciliation of Autonomy and Efficiency", in Villanueva, Enrique (ed.), Legal and Political Philosophy: Social, Political, \& Legal Philosophy, vol. 1, Amsterdam, Rodopi, 2002.

Kronman, Anthony T. and Posner, Richard A. (eds.), The Economics of Contract Law, Boston, Little, Brown and Company, 1979.

LANDO, Henrik and Rose, Caspar, "On the Enforcement of Specific Performance in Civil Law Countries", International Review of Law and Economics, vol. 24, 2004.

LEFF, Arthur Allen, "Contract as Thing", American University Law Review, vol. 19, 1970.

—, "Economic Analysis of Law: Some Realism About Nominalism”, Virginia Law Review, vol. 60, 1974.

LEIB, Ethan J., "On Collaboration, Organizations, and Conciliation in the General Theory of Contract Law", Quinnipiac Law Review, vol. 24, 2005.

LEITER, Brian, "Beyond the Hart/Dworkin Debate: The Methodology Problem in Jurisprudence", American Journal of Jurisprudence, vol. 48, 2003.

Llewellyn, Karl N., "Some Realism About Realism - Responding to Dean Pound", Harvard Law Review, vol. 44, 1931.

-, "What Price Contract? - An Essay in Perspective", Yale Law Journal, vol. 40, 1931.

- The Common Law Tradition: Deciding Appeals, Boston, Little, Brown, 1960. 
SOME REFLECTIONS ON CONTRACT LAW THEORY

LOOKOFSKY, Joseph, Understanding the CISG in the USA, 2nd. ed., The Hague, Kluwer Law International, 2004.

MACAULAY, Stewart, "Non-Contractual Relations in Business: A Preliminary Study", American Sociology Review, vol. 28, 1963.

et al., Contracts: Law in Action, 2nd. ed., Newark, LexisNexis, vols. I \& II, 2003.

MARSH, P.D.V., Comparative Contract Law, EnglandFrance-Germany, Aldershot, Gower, 1994.

MaYer, Caroline E., "Win Some, Lose Rarely? Arbitration Forum's Rulings Called One-Sided", Washington Post, March 1, 2000.

Milsom, S. F. C., A Natural History of the Common Law, New York, Columbia University Press, 2003.

MOORE, Michael S., "A Theory of Criminal Law Theories", Tel Aviv University Studies in Law, vol. 10, 1990.

- "Theories of Areas of Law", San Diego Law Review, vol. 37, 2000.

MuPHY, Liam, "Promise and Practice" (unpublished manuscript), 2003.

MURRAY, John Edward Jr., Murray on Contracts, 4th. ed., Newark, N.J., LexisNexis, 2001.

NCLC (National Consumer Law Center), Press Release: "New Trap Door for Consumers: Card Issuers Use Rubber-Stamp Arbitration to Rush Debts Into Default Judgments", February 17, 2005, http://www. consumerlaw.org/initiatives/model/content/Arbitration. NAF.pdf.

OMAN, Nathan, "Unity and Pluralism in Contract Law", Michigan Law Review, vol. 103, 2005.

, "Corporations and Autonomy Theories of Contract: A Critique of the New Lex Mercatoria", Denver University Law Review, forthcoming, 2005. 
Owen, David (ed.), Philosophical Foundations of Tort Law, Oxford, Clarendon Press, 1995.

PATTERSON, Dennis M., "An Open Letter to Professor James Gordley", Wisconsin Law Review, vol. 1991.

Penner, J. E., The Idea of Property in Law, Oxford, Clarendon Press, 1997.

PERILlO, Joseph M., "Misreading Oliver Wendell Holmes on Efficient Breach and Tortious Interference", Fordham Law Review, vol. 68, 2000.

PERRY, Stephen R., "Interpretation and Methodology in Legal Theory", in MARMOR, Andrei (ed.), Law and Interpretation, Oxford, Clarendon Press, 1995.

- , "Hart's Methodological Positivism", Legal Theory, vol. 4, 1998.

PosNer, Eric, "Economic Analysis of Contract Law After Three Decades: Success or Failure?", Yale Law Journal, vol. 112, 2003.

-, "Contract Theory", in GoldING, Martin P. and EDMundson, William A. (eds.), The Blackwell Guide to the Philosophy of Law and Legal Theory, Oxford, Blackwell Publishing, 2005.

Posner, Richard A., Economic Analysis of Law, 6th. ed., New York, Aspen Publishers, 2003.

—_, "Law and Economics - Contracts", IVR Encyclopaedia of Jurisprudence, Legal Theory, and Philosophy of Law, 2004, http:// encyclopedia.ivr2003.net.

- "The Law and Economics of Contract Interpretation", Texas Law Review, vol. 83, 2005.

Postema, Gerald J., (ed.), Philosophy and the Law of Torts, Cambridge, Cambridge University Press, 2001.

PRATT, Michael, "Scanlon on Promising", Canadian Journal of Law and Jurisprudence, vol. 14, 2001. 
RAKOFF, Todd D., "Contracts of Adhesion: An Essay in Reconstruction", Harvard Law Review, vol. 96, 1983.

RAZ, Joseph, "Promises and Obligations", in HACKER, P. M. S. and RAZ, J. (eds.), Law, Morality and Society, Oxford, Clarendon Press, 1977.

-, "Promises in Morality and Law" (book review), Harvard Law Review, vol. 95, 1982.

- The Morality of Freedom, Oxford, Clarendon Press, 1986.

- Ethics in the Public Domain, Oxford, Clarendon Press, 1994.

- "On the Nature of Law", Archiv für Rechts- und Sozialphilosophie, vol. 82, 1996.

- "Can There Be a Theory of Law?", in GolDING, Martin P. and EDMUNDSON, William A. (eds.), The Blackwell Guide to the Philosophy of Law and Legal Theory, Oxford, Blackwell Publishing), 2005.

SCANLON, Thomas M., "Promises and Practices", Philosophy and Public Affairs, vol. 19, 1990.

- "Promising", in CRAIG, E. (ed.), Routledge Encyclopedia of Philosophy, London, Routledge, 1998, http:// www.rep.routledge.com/article/L118.

- "Promises and Contracts", in BEnson, Peter (ed.), The Theory of Contract Law: New Essays, Cambridge, Cambridge University Press, 2001.

SCHWARTZ, Alan, "The Case for Specific Performance", Yale Law Journal, vol. 89, 1979.

- "Relational Contracts in the Courts: An Analysis of Incomplete Agreements and Judicial Strategies", Journal of Legal Studies, vol. 21, 1992.

SCHWARTZ, Alan and SCOTT, Robert E., "Contract Theory and the Limits of Contract Law", Yale Law Journal, vol. 113, 2003. 
SHAVELL, Steven, Foundations of Economic Analysis of Law, Cambridge, Massachussets, Harvard University Press, 2004.

SHIFFRIN, Seana Valentine, "The Divergence of Contract and Promise", Harvard Law Review, vol. 120, 2007.

Simmonds, N. E., "The Possibility of Private Law", Law, Values and Social Practices, in TASIOULAS, John (ed.), Aldershot, Dartmouth, 1997.

- "Contract Law, theories of", in CRAIG, E. (ed.), Routledge Encyclopedia of Philosophy (Online), 2001, http://www.rep.routledge.com/article/T065.

Simpson, A. W. B., A History of the Common Law of Contract, Oxford, Clarendon Press, 1975.

- "Innovation in Nineteenth Century Contract Law", Law Quarterly Review, vol. 91, 1975.

SlaWson, W. David, "Standard Form Contracts and Democratic Control of Lawmaking Power", Harvard Law Review, vol. 84, 1971.

SMITH, Stephen A., "Towards a Theory of Contract", Oxford Essays in Jurisprudence, in HORDER, Jeremy (ed.), Fourth Series, Oxford, Oxford University Press, 2000.

- Introduction to Contract Theory, Oxford, Clarendon Law Series, 2004.

STEIn, Peter, "Donellus and the Origins of the Modern Civil Law", in ANKUM, J. A. et al. (eds.), Mélanges Felix Wubbe Friboug, Switzerland, University Press Fribourg, 1993.

StolJAR, S. J., A History of Contract at Common Law, Canberra, Australian National University Press, 1975.

Symposium, "Freedom from Contract", Wisconsin Law Review, vol. 2004.

WEINRIB, Ernest J., The Idea of Private Law, Cambridge, Massachussets, Harvard University Press, 1995. 
SOME REFLECTIONS ON CONTRACT LAW THEORY

- "Punishment and Disgorgement as Contract Remedies", Chicago-Kent Law Review, vol. 78, 2003.

ZIPURSKY, Benjamin C., "Pragmatic Conceptualism", Legal Theory, vol. 6, 2000.

, "Pragmatic Conceptualism in Jurisprudence", unpublished manuscript, 2005. 